\title{
Substantivní teorie vojenského převratu: prííčinné faktory
}

\author{
Substantive Theories of Military Coup: Causal Factors
}

\author{
LUKÁŠ MARTINÁK ${ }^{1}$
}

\begin{abstract}
The review article provides an analysis of Anglo-Saxon literature specialized in military coup research, especially that which focused on substantive theories of military coup inception and execution. The main goal of the article is to present previous military coup research and to minimize the conceptual gap between Anglo-Saxon and Czech political science with regard to the understanding of such a significant phenomenon. Starting with a definition of the military coup, the article's goal is to describe and critically analyze ten separate substantive theories (such as the theory of military centrality, the theory of the coup trap, contagion theory, or linkage and leverage theory). From a Central European perspective, these theories offer a sufficient basis for additive coup research focused on European or Middle Eastern conditions. However, from the perspective of the requirements of a generally applicable formal theory, substantive theories provide limited conceptual instruments, which should be used carefully with respect to the specifications of particular cases.
\end{abstract}

Keywords: Military Coup, Coup d'État, Theoretical Approaches, Civil-Military Relations

\section{1. Úvod}

Státní převraty představují fenomén, v jehož stínu se přepisovala historie nejen střední Evropy, ale bez nadsázky zemí celého světa. Jejich úspěšná provedení či zmařené pokusy se značnou měrou podílely na dynamice společenských změn přímo formujících politické, sociální i ekonomické prostředí na úrovni jednotlivých států, přeneseně pak i celého mezinárodního systému. Rusko 1825, Francie 1851, Mad'arsko 1919, Litva 1926, Španělsko 1931, Německo 1934, Rakousko 1934, Řecko 1967, Polsko 1981, Ukrajina 2014 - to je jen výběr z celé řady státních převrati̊, které provázely dějiny evropských zemí od „dlouhého“ devatenáctého století přes „krátké“ století dvacáté až do současnosti. Koneckonců ani historie Československa není skoupá na události, jež lze bez nánosů ideologické a státotvorné mytologie nazvat státním převratem: protiroajalistický převrat 1918,

\footnotetext{
${ }^{1}$ Ministerstvo obrany České republiky, Tychonova 1, 16001 Praha - Dejvice, Česká Republika / Ministry of Defence, Czech Republic. E-mail: 1.martinak@seznam.cz
} 
protofašistický převrat 1938, komunistický převrat 1948 nebo protikomunistický převrat 1989.

$\mathrm{Na}$ základě terminologického slovníku studií státního převratu (StP), který byl předložen $\mathrm{v}$ předchozím textu publikovaném ve Středoevropských politických studiích, je možné definovat vojenský převrat (VoP) jakožto specifickou kategorii StP,

„jehož strůjcem jsou ozbrojené síly převratem stiženého státu. Ozbrojené síly mohou při jeho realizaci vystupovat jako jeden aktér, nebo je iniciátorem převratu jejich fragment, který tak operuje proti rozkazům centrálního velení. Ozbrojené síly realizují převrat zcela samostatně, nebo za přizvání civilní politické elity, která však vystupuje jako sekundární aktér“" (Martinák 2015: 112).

Jeho nebezpečí tkví především v tom, že ozbrojené síly jakožto obrana před hrozbami pocházejícími z mezinárodního anarchického prostředí zaměři svou pozornost na domnělého „vnitřního nepř́tele“, kterého lze definovat takřka bez omezení - dle potřeb vojenských a $\mathrm{k}$ nim prrivinutých politických elit. VoP podvazuje mechanismus politického systému, nebot' civilní charakter politického rozhodování je nezbytnou podmínkou pro plynulý rozvoj demokracie. Je tudíž možné jej považovat za mnohem nebezpečnější „,náhlou protiústavní a protiprávní vnitropolitickou akc[i], jejímž zamýšleným cílem je odstranění stávající vlády nebo změna politického režimu za použití násilí, či pod hrozbou jeho užiti““ (tamtéž: 111) - tedy formu StP.

Problematice VoP se již od šedesátých let dvacátého století věnuje řada badatelů, zejména pak politických vědců a vědkyň anglosaské provenience. Jednou z hlavních otázek (možná i nejdůležitějšî), kterou se dosavadní studie snažily zodpovědět, je př́činnost převratu: Kdy k VoP dochází? (nutné podmínky jeho výskytu); Jaké jsou př́činy VoP? (faktory rozhodující o jeho provedení - v ideálním kauzálním vyjádření dostačující podmínky, jež jsou však reálně těžce rozpoznatelné). V důsledku závažnosti této otázky byly zformulovány desítky teorií a v jejich rámci kauzální modely, které vysvětlují vznik VoP na základě př́tomnosti odlišných faktorů. Tyto teorie se do jisté míry vzájemně doplňují, avšak v některých pŕṕpadech jsou v konfliktu a jedna druhou vylučuje. Tato fragmentace dosavadního výzkumu VoP (ale celkově i StP) je z pohledu snahy o vyjádření univerzální, formální teorie VoP problémem, nicméně jednotlivé substantivní teorie nabízejí možná vysvětlení vzniku a úspěchu převratu $v$ konkrétních prípadech, definovatelných konkrétní sadou kauzálních faktorů.

Právě tato prŕnosnost je hlavním motivem tohoto článku, který předkládá popisný přehled ústředních teoretických proudů ve výzkumu VoP (v omezené míre i StP). Cílem tohoto přehledového textu je poskytnout českým studentům a badatelům v oblasti politické vědy sadu konceptuálních nástrojů využitelných při navazujícím výzkumu VoP. Nenabízí však kritickou analýzu míry relevance jednotlivých teoretických prrístupů, čímž se vyvaruje apriorního omezení ve výběru 
a tím i možné chybné volbě výzkumníka. Jednotlivé části jsou věnovány deseti konceptuálním konstrukcím nahlížení na př́činnost VoP, které nejsou v tuzemské politologii dostatečně reflektovány (stejně jako samotný výzkum státního převratu). Následující text se tak pokouší nabídnout badatelům české politologické obce možnost rozšíření jejich výzkumného instrumentáře a alespoň o něco zmenšit mezeru mezi úrovní studií $\mathrm{VoP}(\mathrm{StP})$ v české a anglosaské politické vědě, jež se zdá být takřka propastná.

\section{Zavedené substantivní teorie příčin vojenského převratu}

Dlouhý vývoj, jímž studie vojenských převratů prošly od šedesátých let dvacátého století do druhého desetiletí století jednadvacátého, dal vzniknout celé řadě odlišných teoretických př́stupů v rozpoznávání, definování a ověřování okolností, které mohou být dosazeny do rovnice VoP na místa nezávislých proměnných. $\mathrm{V}$ rámci každého $\mathrm{z}$ těchto prístupů byly upřednostněny $\mathrm{z}$ celospolečenského kontextu vypreparované a separátně popsané veličiny, jejichž kauzální efekt (pod vlivem rozvoje behavioralismu ve společenskovědních oborech se v převážné většině jednalo o kvantitativní studie) na výskyt $\mathrm{VoP}$ byl v různé míre prokázán. Po této prvotní fázi byly postupně zformulovány teoretické koncepce - složené soustavy na sebe navazujících (avšak nezrrídka se prolínajících) proměnných, $\mathrm{v}$ nichž vždy jedna z nich byla dosazena na pozici fundamentální proměnné. Ta byla přitom často projektována do názvu příslušné substantivní teorie, díky čemuž jsou ústřední hypotézy jednotlivých teorií poměrně snadno identifikovatelné.

Navzdory jejich komplexnosti bývá platnost závěrů substantivních teorií omezena časovým nebo prostorovým rámcem, do něhož jsou zasazeny př́padové studie poskytující dané teorii empirickou bázi. Větši část výzkumů VoP je zaměřena na státy subsaharské Afriky a Latinské Ameriky a s tím, jak se postupně snižoval počet nově uskutečněných VoP nejen na těchto kontinentech, slábl i mezi badateli zájem o studium VoP. Výsledkem je tedy výrazně specificky orientované poznání, jež sice může, ale $s$ největší pravděpodobností nebude schopno vysvětlit prríčiny konkrétního vojenského převratu, který se udál v podmínkách zcela odlišných od dosud preferovaného územního i dobového vymezení. Jediným možným dalším krokem výzkumníka, který si klade za cíl nalézt obecně platné determinanty VoP, je proto v souladu s rozšířením empirického záběru provedení syntézy všech relevantních substantivních teorií, jejichž pomocí byla jistá specifická kauzální vazba mezi závislou a nezávislými proměnnými rozpoznána, a díky tomu nalézt kauzální vazby s obecnou platností.

\section{a. Teorie vojenské dostřednosti}

V souladu s tím, co bylo výše řečeno o substantivních teoriích ve studiích VoP, lze z názvu této teorie (military centrality theory) zcela jasně odvodit hlavní nosné myšlenky, které ji podpíraji: posuny ozbrojených sil ve struktuře politického 
systému směrem do mocenského centra a následný nevyhnutelný konflikt s civilním vládním aparátem. Autoři aplikující teorii vojenské dostřednosti s cílem určit prŕćčiny $\mathrm{VoP}$ kladou důraz na rozpoznání parametrů ozbrojených sil jakožto potenciálního strůjce převratu, čímž pokládají těžišsě pozornosti na stranu subjektu. Zjednodušeně řečeno, pravděpodobnost uskutečnění VoP je dle této teorie odvislá od charakteristik potenciálního strůjce.

Základy uvedeného př́stupu byly položeny již v prvních rozsáhlejších studiích o VoP (např́klad Finer 1962; Janowitz 1977; Nordlinger 1977), v nichž je kladen značný důraz na fakt, že jsou to především bývalé kolonie, kde armády jako jediné subjekty disponují konzistentní pevnou strukturou a mají př́stup k rozsáhlým zdrojům. V těchto málo rozvinutých společnostech představuje armáda technologicky, organizačně a personálně dobře zajištěný celek, jehož vliv je navíc upevněn de iure i de facto schopnostmi použít násilné prostředky $\mathrm{k}$ naplnění svých cílů (Mbaku 1994: 247). Zejména kvůli esprit de corps - tomuto typickému stmelujícímu faktoru - se však obsahový význam těchto cílů v očích armády často rozchází s představami vládní garnitury (Kposowa a Jenkins 1993: 130). Armáda, dřive vytvořená koloniální velmocí (společně se soustavou dosazených místních vládců loajálních vi̊či metropoli) k prosazení jejích mocenských zájmů vůči domorodému obyvatelstvu, se po vlně dekolonizace situovala do role přesahující obvyklý rámec její působnosti: do role budovatele národa a modernizátora.

Zejména $\mathrm{v}$ šedesátých letech dvacátého století byla značná část badatelské pozornosti věnována důvodům jednání ozbrojených sil, které vede bud'to k obraně politického režimu, či naopak k jeho svržení. Slovy S. Huntingtona bylo „spotřebováno mnoho inkoustu a času“ nad debatami o soudobém problému značně ovlivňujícím politický vývoj $\mathrm{v}$ zemích třetího světa: Roli armády $\mathrm{v}$ modernizačním procesu, $\mathrm{v}$ němž mohla zastávat pozici klíčového progresivního, nebo konzervativního aktéra (Huntington 1968: 219). Armáda, rekrutující se především ze středních socioekonomických vrstev populace, se prrirozeně stává obráncem zájmů této skupiny a negativně vnímá snahy o mocenskou redistribuci ve prospěch nepočetné oligarchie nebo početným nižším vrstvám (tamtéž: 221). Tímto směrem orientovaná politika vlády (či pouhý deklarovaný úmysl vnitropolitického aktéra vážně aspirujícího na sestavení vlády ji provádět) tak přímo zasahuje do sfér vlivu, které si armáda coby garant modernizace a stability nárokuje, čímž se nevyhnutelně politizuje. Kompetenční či personální zásahy vlády do velitelského sboru takto zpolitizované armády, z jejíhož pohledu se de facto jedná o útok civilně-politické elity proti vojensko-politické elitě, lze za těchto okolností přirovnat $\mathrm{k}$,hozené rukavici““.

Tyto studie později vedly $\mathrm{k}$ formulaci teorie vojenské dostřednosti. Z její perspektivy lze vysvětlit i proces postupného vytlačování armády ze sféry politiky a skutečnost, že vojenské režimy ztrácely na přitažlivosti, jež je jinak typická zejména pro Latinskou Ameriku. Ruku v ruce s hospodářským růstem a intenzifikací sociální mobilizace postupuje totiž i rozvoj občanské společnosti, 
a vlivem sílící urbanizace, zvyšování úrovně vzdělání, zlepšování socioekonomické situace a prosazování myšlenek politického pluralismu sílí také ve většině armád latinskoamerických (ale i asijských) zemí snahy směřuící proti politickému angažmá ozbrojených sil (Dix 1994: 445-446).

Teorie pracuje s několika premisami, jež jsou vyjádřením ověrené kauzální vazby mezi VoP a atributy armády (subjektu VoP), resp. vztahu armády k vládě a/nebo celkovému politickému režimu (objektu VoP). Řada badatelů (např́íklad Wells 1974; Johnson et al. 1984; Wells a Pollnac 1988; Jenkins a Kposowa 1990, 1992) zjistila, že existuje silný prrícinný vztah mezi velikostí armády a armádního rozpočtu a pravděpodobností realizace $\mathrm{VoP}$ (popř. prímo vzniku vojenské diktatury; Acemoglu et al. 2008: 810; Brauner 2012: 4). Č́m větším počtem svých příslušníků armáda disponuje a čím větší podíl na státním rozpočtu představuje položka alokovaná pro resort obrany, tím zranitelnějším se vládnoucí režim vưči potenciálnímu VoP stává. Velikost armády, vyjádřitelná poměrem aktivně sloužících př́slušníků ozbrojených sil k celkovému počtu obyvatel, je strukturálním faktorem, poněvadž je výsledkem dlouhodobé politiky vyvěrající z povahy vnitrostátního či mezinárodního bezpečnostního prostředí nebo z politické kultury formované vojenskou tradicí. Stejně tak je ale i motivačním faktorem. Početná armáda totiž představuje významnou zájmovou skupinu (slovy E. Nordlingera skupinu s korporátní identitou), jejíž velení citlivě reaguje na jakékoliv ohrožení svého vlivu na rozhodování státu. Při jeho oslabení či zpochybnění je armáda svou velikostí motivována k provedení opatření s cílem obnovit či posílit svou mocenskou pozici $\mathrm{v}$ rámci politického systému.

Objem financí vyčleněných pro potřeby armády je veličinou odlišného charakteru. Jako část státního rozpočtu je schvalován s krátkodobou periodicitou, obvykle na období jednoho roku. Protože jsou vojenské výdaje, společně s určitou mírou společenské autonomie ozbrojených sil a jejich výlučného práva bránit stát „se zbraní v ruce“, zdrojem korporátní identity tohoto subjektu (Nordlinger 1977: 68-78; Mbaku 1994: 247), je jejich projekce do míry rizika převratu neoddiskutovatelná. Vysoký rozpočet umožňuje armádě investovat do budování vlastních finančních zdrojů a činí ji tak méně závislou na rozhodování vlády. Umocňuje $\mathrm{v}$ př́slušnících ozbrojených sil pocit sociální exkluzivity, od níž je jen krok k exkluzivitě politické. Jinými slovy, vysoký rozpočet (v mírové době) stimuluje růst mocenského potenciálu, a tím i snahy tuto moc využít $\mathrm{k}$ intervenci do politické i ekonomické sféry státu. Z těchto skutečností lze pak snadno odvodit, jaký bude mít na riziko převratu dopad setrvale se snižující podíl státního rozpočtu alokovaný pro resort obrany. Z chronicky podfinancovaného stavu ${ }^{2}$ se stává strukturální faktor, který motivuje k přehodnocení loajality ozbrojených sil $\mathrm{k}$ politické garnituře země.

2 Pravidelně snižovaný rozpočet ve střednědobém (3 až 5 let) a dlouhodobém (6 let a více) horizontu. 
Část autorů pracujících s teorií vojenské dostřednosti zahrnula do této koncepce další veličinu, která, dle jejich závěrů, ve velké míře přispívá k růstu rizika převratu (viz schéma 1). Termín „frakcionalizace armády“ (Johnson et al. 1984), která má svůj původ v procesu, pro nějž se rovněž vžilo označení „afrikanizace“ (Smaldone 1974), ${ }^{3}$ vyjadřuje strukturální stav politického systému, v němž se spolu pojí dva druhy tenzí. První pochází z vnějšku, tedy ze společnosti, jejíž etnická rozmanitost se projektuje do heterogenity ozbrojených sil. Důsledkem tohoto tlaku je zájmové ,štěpení uvnitř uniformovaných šikư“ (Barany 2013: 64) dle národnostní (či náboženské) identity zasahující do vyšších pater velitelské struktury, přičemž obsadit nejdůležitější velitelské funkce může jen jedna ze soupeř́ících frakcí. Druhá směřuje (holisticky pojato) z ozbrojených sil do politického centra režimu, jež je vưči armádě taktéž definováno etnicky příznivým či neprríznivým rozložením sil; cílem tohoto tlaku je prosadit korporátní zájem armády, a to i za cenu VoP.

\section{Schéma 1: Zjednodušený kauzální model VoP dle teorie vojenské dostřednosti}

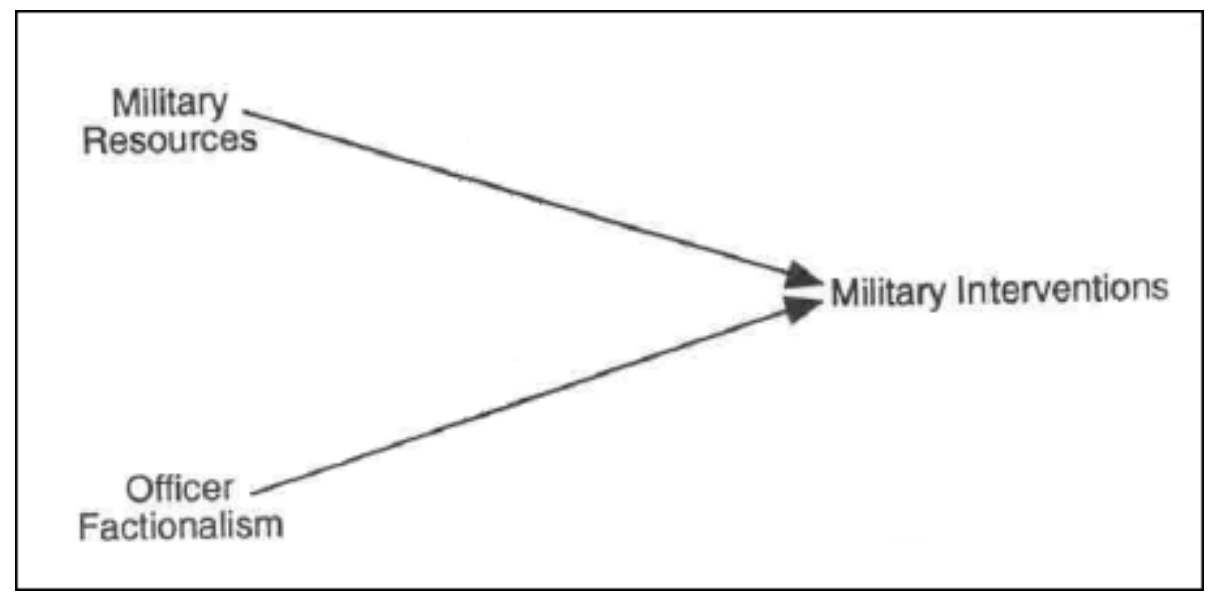

Zdroj: upraveno z Kposowa, Jenkins 1993: 141.

Ačkoli teorie vojenské dostřednosti nabízí konceptuální návod, jak rozklíčovat jednání armády - subjektu možného VoP, jejichž motivace a v omezené míre vlivu jejího vnitřního stavu na riziko převratu -, ponechává mnoho otázek bez odpovědi. Zaprvé téměř ignoruje roli objektu převratu (vlády, režimu) v událostech předcházejících VoP nebo pokusu o něj. Zredukovala ji na oblast rozhodování o výši finančních zdrojů, které jsou uvolňovány pro potřeby armády. Zadruhé

\footnotetext{
3 Afrikanizací rozumí J. Smaldone řízenou postkoloniální transformaci ozbrojených sil nově vzniklých států, při níž byl etnicky kompaktní důstojnický sbor nahrazen př́islušníky různých etnik obývajících dané území. Tato etnická heterogenita velitelských stupňů vedla k celkové frakcionalizaci armády na liniích etnického původu a z nich vyplývajících odlišných zájmů. Afrikanizace je př́značná pro země subsaharské Afriky na počátku postkoloniální éry.
} 
nezahrnuje do hodnocení rizika VoP charakter prostředí, v němž se potenciální aktéŕi VoP střetávají. Typ politického režimu není zohledněn navzdory tomu, že je prokázána výrazná disproporce mezi počty VoP (StP) v demokratických a nedemokratických režimech (např́klad Brauner 2012). Zatřetí dostatečně nereflektuje dynamiku vztahů uvnitř ozbrojených sil. Př́liš zjednodušující holistické chápání ozbrojených sil jakožto kompaktního politického aktéra (s jistou výjimkou konceptu frakcionalizace) nepředkládá řešení zakomponování takových konfliktních linií, jež vyplývají z rozdílů druhů vojsk či elitních a pravidelných vojenských útvarů.

\section{b. Teorie protiváhy}

Jestliže teorie vojenské dostřednosti nezahrnuje do svého kauzálního modelu VoP, inter alia, podíl vlády na procesu utváření podmínek pro realizaci převratu, koncepční př́stup, jež můžeme zjednodušeně nazvat „teorií protiváhy“ (counterbalancing, structural coup-proofing), tento nedostatek do určité míry napravuje. A jak si ukážeme, částečně teorii vojenské dostřednosti doplňuje a částečně zároveň zpochybňuje.

Úhel pohledu, jímž autoři aplikující teorii protiváhy nahlížejí příčiny VoP, vychází z instrumentální výbavy vládnoucího režimu jakožto klíčové veličiny. Režim je nucen hrozbě převratu čelit, a to zejména za použití preventivních politických nástrojů. V návaznosti na diskutovanou kategorizaci přícin VoP a jejich charakteristiku lze účinně předcházet převratům pouze marginalizací jejich strukturálních faktorů. Pro účely prevence se tak vládám nabízí sada nástrojů, jejichž přehled a definici předkládá ve své práci J. Quinlivan (1999: 133, 135):

(a) vytvoření vojenské struktury paralelní vưči pravidelné armádě;

(b) rozvoj komplexního systému zpravodajských a bezpečnostních služeb s prekrývající se působností;

(c) kontrola vojenského rozpočtu;

(d) profesionalizace ozbrojených sil;

(e) využití loajality založené na rodinné, etnické nebo náboženské sdílené identitě.

Paralelní ozbrojené složky s vlastní strukturou velení bezprostředně vázaným na politické špičky a bez jakéhokoli subordinačního vztahu k velení pravidelné armády mohou mít podobu např́klad pohraniční stráže, polovojenských jednotek, milicí či prezidentské gardy (Feaver 1999: 225). Z pohledu strůjců převratu totiž je, jak podotýká B. Geddesová, nejhorším možným scénářem taková situace, v níž by jednotky provádějící VoP byly nuceny zlomit odpor jiných složek ozbrojených sil bojovými akcemi (1999: 126). Bez ohledu na podobu, jakou na sebe „paralelní armáda“ bere, je tedy její účel (v prevenci VoP) vždy stejný: Vytvořit překážky možnému vojenskému převratu cestou vyvažování sil (Belkin a Schofer 2003: 596; 
Powell 2014: 175). Její efektivita tkví v disponování donucovacími prostředky a možností použít násilí, čímž de facto představuje pro pravidelnou armádu vnitrostátního rivala (Belkin a Schofer 2005: 155). Věrnost paralelní armády si přitom režim zajišt’uje tím, že jejím př́slušníkům umožňuje exkluzivní př́stup k jinak těžce dosažitelnému ekonomickému, sociálnímu a mnohdy i politickému postavení.

Účel budování sítě většího množství zpravodajských a bezpečnostních služeb s překrývající se působností je podobný, jako tomu je u paralelní armády. Zaprvé jednotlivé služby provádějí dozor nad činností těch ostatních, poněvadž účast zejména vojenských zpravodajských služeb na př́pravě VoP nebývá výjimkou. Zadruhé dohlížejí na vnitřní stav ozbrojených sil, přičemž jsou schopné provádět nebo informačně zabezpečovat personální čistky v armádní velitelské struktuře na všech jejích úrovních. Zatřetí monitorují a hodnotí „,všeobecný pořádek“ (Powell 2014: 149) - tedy vývoj bezpečnostní situace, jejíž zhoršení může plnit funkci spouštěcího faktoru pro provedení VoP. Složitá sít' zpravodajských a bezpečnostních služeb tak má významný preventivní/demotivační vliv na potenciální strůjce př̀vratu.

Třetím nástrojem režimu sloužícím $\mathrm{k}$ minimalizaci jeho zranitelnosti vůči VoP je kontrola nad vojenským rozpočtem. Při práci s touto veličinou ovšem dochází $\mathrm{k}$ rozporu s teorií vojenské dostřednosti. Zatímco ta vnímá proměnnou „výše financování armády" coby veličinu mající s VoP příčinný vztah přímé úměrnosti, autoři vycházející z teorie protiváhy (kupř́kladu Quinlivan 1999; Leon 2012; Powell 2012, 2014; dále také Huntington 1968, 1991) zdůrazňují vliv vysokého rozpočtu na snižování rizika převratu. ${ }^{4}$

Odpověd' na zdánlivou neřešitelnost tohoto sporu se naskýtá při podrobnějším pohledu na účel, za jakým je financování ozbrojených sil prováděno. Primárně je klíčové pro udržování, nebo videálním př́padě navyšování bojeschopnosti armády cestou zabezpečení jejích lidských a materiálních zdrojů. Tyto, slovy S. Huntingtona, „vojenské hračky“ (1991: 252) stimulují kvalitativní i kvantitativní růst schopností ozbrojených sil vést silové operace při obraně i útoku, ale rovněž, jako vedlejší efekt, zvyšují vliv armády na mechanismus politického systému, jehož jsou aktérem (což ale nemusí nutně mít za následek zvýšení rizika převratu). Stejně tak je pro vojáky určujícím faktorem jejich socioekonomické zabezpečení a z toho plynoucí společenský status. ${ }^{5}$ Nenaplnění těchto potřeb vede $\mathrm{k}$ neuspokojivému stavu uvnitř ozbrojených sil a degradaci

4 Tato hypotéza je v př́krém rozporu se závěrem, který předkládají např́klad P. Collier a A. Hoefflerová. Na základě studia převratů v zemích subsaharské Afriky tvrdí, že zvyšování výdajů na armádu ji motivuje $\mathrm{k}$ dalšímu rozšiřování mocenské základny (2007: 20).

5 Pro správnost tohoto předpokladu hovoří existence ověřené kauzality mezi úspěšným VoP a navýšením vojenského rozpočtu v popřevratovém období. Nabízí se tak velmi pravděpodobné vysvětlení, že nízké financování ozbrojených sil má motivační efekt na jejich odhodlání realizovat vojenský převrat (Leon 2012: 5). 
úrovně obranyschopnosti proti bezpečnostním hrozbám danému státu. ${ }^{6}$ V této souvislosti je nutné připomenout, že rovněž vydržování „paralelní armády“ představuje značné rozpočtové zatížení (Quinlivan 1999: 153). Její případné podfinancování tak logicky implikuje další zvýšení rizika převratu. Vysoký vojenský rozpočet v období míru se tak zdá být spíše symptomatickým projevem dominance ozbrojených sil nad civilní politickou reprezentací země (např́ílad dosaženou dříve uskutečněným VoP), nežli příčinou vojenského převratu. Tou se přitom stává nikoli na základě své absolutní výše, nýbrž kvůli snižující se tendenci. Jestliže je postavení armády ohroženo redukcí jejích přijmů, pak toto snížení př̌edstavuje potenciální strukturální faktor a současně je př́ležitostí k uskutečnění VoP.

Další z nástrojů posilování odolnosti režimu vůči vojenskému převratu, jímž je podle J. Quinlivana využití etnických, konfesních či rodinných vazeb pro zajištění loajality potenciálně nebezpečných vnitropolitických aktérů, je oproti proměnné „frakcionalizace“ na etnickém základě, obsažené v teorii vojenské dostřednosti, pojat odlišně. Nepotistické struktury, o něž mnohé nedemokratické režimu opírají svou existenci a zajišt'ují jejich prostřednictvím vlastní bezpečnost, jsou indikovatelné poměrem mezi skupinou obyvatelstva sdílející s vládnoucí elitou stejnou širši identitu a celkovou populací (tamtéž: 135-136). Obdobně jako teorie předchozí zahrnuje také teorie protiváhy etnickou, národnostní, konfesní či kmenovou rozmanitost společnosti zkoumaného státu do pomyslného vzorce, jímž lze stanovit riziko VoP. Zatímco však teorie vojenské dostřednosti vnímá celkově tuto heterogenitu jako rizikovou, teorie protiváhy dává jednotlivé skupiny do vzájemného poměru a definuje je dle jejich režimní nebo ne-režimní (popř̀. protirežimnî) pozice v politickém systému.

Konečně profesionalizace ozbrojených sil, jejíž význam pro vnitropolitickou stabilitu zdůrazňuje především S. Huntington (1957: 11-18), spočívá v procesu depolitizace armády cestou vzdělávání a budování profesní identity svých příslušníků na úkor identity korporátní. Z holistické, vnější perspektivy bývá tento proces provázen snížením počtu aktivně sloužících vojáků, daného přechodem od masové armády, často založené na povinné vojenské službě, $\mathrm{k}$ armádě profesionální (Martinák 2010: 55-56). Až na tento vedlejší př́íznak je nicméně faktor profesionalizace, vzhledem ke své nesnadné kvantifikovatelnosti, pro potřeby dobré operacionalizace př́slovečnou „noční můrou“, proto by měl být do kauzálního modelu VoP zahrnut s omezenými očekáváními.

Díky teorii protiváhy byl původní kauzální model doplněn o proměnné, které se vážou na jednání objektu potenciálního VoP, čímž byla zmírněna limitující jednostrannost teorie vojenské dostřednosti. Rovněž konceptem „paralelní

\footnotetext{
${ }^{6}$ Jak správně podotýká J. Powell, důsledek nesplnění finančních požadavků armády je odvislý od typu politického režimu (2014: 177). Bezpečnost státu tak může být ohrožena bud' ze strany nespokojených vojáků (spiše v autoritářských režimech), či oslabením vlastní armády z důvodu nedostatečného materiálního zajištění a platové demotivace jejích př́islušníků (spiše v demokraciích).
} 
armády“ byly vyřešeny nedostatky přiliš holistického pojetí ozbrojených sil jakožto nedělitelného politického aktéra. Navzdory těmto př́nosům ovšem stále přetrvává problém konceptuální mezery v podobě absence zahrnutí politického režimu (polity) coby přícinné veličiny do celkového modelu. Význam charakteru politického režimu na riziko převratu byl naopak ještě zdůrazněn rozdílností motivace, kterou konspirátorům dodává nízký vojenský rozpočet v rámci demokratických a nedemokratických států (Leon 2012: 5-6). Tento faktor si proto bezesporu zasluhuje pozornost. Dalším nedostatkem, jenž je přehlížen oběma výše popsanými teoriemi, je upřednostňování strukturálních faktorů při posuzování př́čin VoP. Kauzální model nadále postrádá větší zohlednění role spouštěcích faktorů, mezi nimiž by měl figurovat kupř́kladu aktuální stav bezpečnostního prostředí, jehož význam rozhodně nelze bagatelizovat.

Tabulka 1: Srovnání uvažovaného účinku př́ičinných faktorů působících na riziko vojenského převratu $\mathrm{v}$ teoriích vojenské dostřednosti a protiváhy

\begin{tabular}{|c|c|c|}
\hline \multirow{2}{*}{ příčinné faktory } & \multicolumn{2}{|c|}{ teoretické přístupy k výzkumu VoP } \\
\hline & $\begin{array}{c}\text { teorie vojenské } \\
\text { dostřednosti }\end{array}$ & teorie protiváhy \\
\hline velikost armády & $\begin{array}{l}\text { její zvyšování zvyšuje } \\
\text { motivaci k VoP }\end{array}$ & - \\
\hline vojenský rozpočet & $\begin{array}{l}\text { s jeho růstem se zvyšuje } \\
\text { pravděpodobnost } \mathrm{VoP}\end{array}$ & $\begin{array}{l}\text { s jeho růstem se snižuje } \\
\text { pravděpodobnost VoP }\end{array}$ \\
\hline etnická heterogenita & $\begin{array}{l}\text { s její projekcí do armády } \\
\text { se zvyšuje riziko VoP }\end{array}$ & $\begin{array}{l}\text { může působit } \\
\text { preventivně proti } \mathrm{VoP}\end{array}$ \\
\hline paralelní armáda & - & prevence vůči VoP \\
\hline sít' zprav. služeb & - & prevence vůči VoP \\
\hline
\end{tabular}

Zdroj: autor.

\section{c. Model Gaussovy křivky: formy politických režimů}

Zahrnutí typologie politických režimů do výzkumu předpokladů výskytu VoP skýtá př́ležitost pro studium geneze univerzálně pojatého fenoménu převratu v diametrálně odlišných prostředích. Konceptuální šíre tohoto studia je dána celou radou různých př́stupů, $\mathrm{z}$ nichž každý typologizuje režimy dle vlastní sady 
určujících parametrů. V rámci studií vojenských (státních) převratů se však jako dominantní prosadil epistemologický proud, zaměrující pozornost badatelů na výzkum možné kauzality mezi VoP a jednotlivými typy režimu definovanými na základě mechanismu distribuce moci mezi vnitropolitickými aktéry - tzv. „,formami politických režimü“ (např́klad Hanneman a Steinback 1990; Levitsky a Way 2006; Wayman a Tago 2009; Goldstone et al. 2010; Bouzid 2011).

V souladu s touto kategorizací se ve výzkumné praxi ustálilo používání dvoupólové škály, jejíž jednotlivé stupně (typy režimu) jsou vzájemně odstupňovány dle klíče „míra demokratičnosti“ (resp. „míra autokratičnosti“). Řada studií (např́klad Hanneman a Steinback 1990; Bouzid 2011), které pro rozeznání faktorů přispívajících ke zvyšování rizika VoP tuto dvoupólovou škálu využívají,, vedla k závěru, že existuje silná kauzalita mezi absencí VoP a režimy, jejichž předlohy se na zmíněné škále nacházejí na obou jejích koncích. ${ }^{7}$

Demokracie (definované nikoli pouze jako institucionální forma, nýbrž především jako normativní rámec) disponuje nástroji civilní kontroly nad armádou v podobě její profesionalizace a odpolitizování a/nebo politické kultury oslabující korporátní identitu př́slušníků ozbrojených sil. Tyto faktory působí ve směru snižování rizika (Hanneman a Steinback 1990: 12; Bouzid 2011: 55). S tím, jak se konkrétní forma režimu na autokraticko-demokratické stupnici vzdaluje od „plně demokratického“8 ideáltypu (Goldstone et al. 2010), se riziko převratu zvyšuje úměrně s postupným naplňováním atributů spojených s režimem, pro nějž se díky práci J. J. Linze ustálilo označení „,autoritativní“ (2000: 159). R Hanneman a R. Steinback, kteří při výzkumu vlivu charakteristik režimu na možnost realizace VoP předložili vlastní typologii, jíž dosáhli syntézou prací G. Almonda a B. Powella (Comparative Politics: A Developmental Approach, 1966), J. Blondela (The Organization of Governments: A Comparative Analysis of Government Structures, 1982) a R. Hannemana (1986), by tuto abstrakci označili jako „diktaturu“, popř. za jednu z „autoritářských variant". Žrejmě nejpřesněji tuto formu režimu, vyznačující se největší zranitelností vǔči VoP, pojmenoval W. Thompson, a to jako „pretoriánský režim“ (Thompson 1974: 241), který tento termín převzal z teoretického modelu S. Huntingtona (1968: 192-237), společně s jeho parametrickou definicí předloženou A. Perlmutterem (1969: 384). ${ }^{9}$

\footnotetext{
${ }^{7}$ Lingvisticky i meritorně je označení těchto dvou protilehlých pólů v souladu s výkladem podstaty demokracie a jejích konkurenčních modelů G. Sartoriho. Autokracie a demokracie představují ideáltypy, které jsou ve vzájemném kontradiktorním vztahu a k nimž se reálné politické režimy svými parametry více či méně přibližují.

8 V indexovém nástroji Polity IV (využit např́klad v Bouzid 2011; Brauner 2012) je tato předloha vyjádřena jako „konsolidovaná demokracie“ (s hodnotou +10$)$.

9 Perlmutter definuje pretoriánský režim na základě osmi parametrů: 1) nízký stupeň společenské koheze, 2) existence proti sobě neprátelsky vystupujících společenských tříd, 3) vysoká úroveň společenské polarizace a absence konsolidované střední třídy, 4) nízká úroveň sociální a materiální mobilizace, 5) prohlubující se propast mezi centrem a periferií, 6) nízká úroveň politické
} 
$\mathrm{Na}$ autokraticko-demokratické stupnici je však patrný zrcadlový efekt, s ohniskem uprostřed škály. Míra zranitelnosti režimu totiž vykazuje podobnou dekrementační tendenci při přibližování posuzovaného režimu k parametrům ,plně autokratického“ ideáltypu (Goldstone et al. 2010), jemuž v názvosloví Hannemana a Steinback odpovídá „režim sovětského stylu“ (1990: 12). Klasická teorie nedemokratických režimů pak pro tento model standardizovala C. Friedrichem (1969: 126) zpopularizovaný termín ,totalitarismus“ “. ${ }^{10}$ Nízká pravděpodobnost vzniku VoP je důsledkem ideologické indoktrinace př́slušníků ozbrojených sil (stejně jako občanské společnosti) a absorpce vyšších a středních stupňů velitelské struktury státním (stranickým) aparátem. Tím je fakticky odstraněna nezávislost armády na politické elitě. Zahrnutím vojenských představitelů do mocenských státních orgánů se tak VoP stává iracionální alternativou. Grafické znázornění vztahu mezi zranitelností režimu a jeho abstraktními modely nacházejícími se na autokraticko-demokratické škále by pak videálním prípadě přpomínalo tzv. Gaussovu křivku (viz schéma 2).

Schéma 2: Zjednodušené znázornění funkce mezi mírou zranitelnosti režimu vi̊či VoP a mírou naplnění parametrů ideáltypu autokracie, resp. demokracie

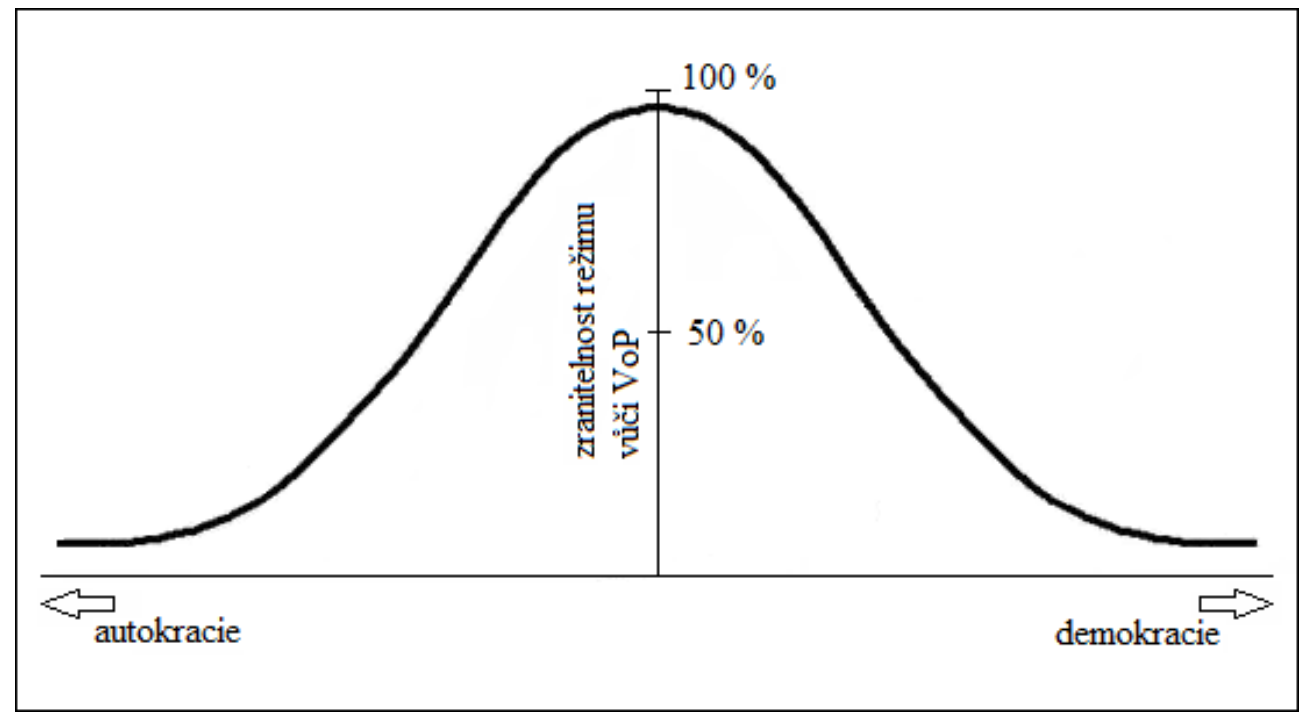

Zdroj: autor.

Jednoduchost tohoto př́stupu k analýze prríčin VoP může být jeho silnou, ale také slabou stránkou. Ignoruje totiž několik důležitých faktorů, které mohou hrát v procesu utváření podmínek prríznivých pro vznik převratu nezanedbatelnou roli.

institucionalizace a nedostatek podpory struktuře politického systému, 7) př́tomnost slabých a neefektivních politických stran, 8) časté civilní zásahy do záležitostí armády.

${ }^{10} \mathrm{~V}$ rámci Polity IV označen jako „plně institucionalizovaná autokracie“ $(-10)$. 
Forma politického režimu totiž představuje pouze jeden - jakkoli signifikantní parametr státu. Autoři aplikující metodu autokraticko-demokratické škály tak do svých úvah např́klad nezahrnují význam vnitřního uspořádání státního aparátu, ani podobu hospodářského systému, který do značné míry ovlivňuje schopnost státu plnit nejen své primární funkce. Tento přístup taktéž nepřináší oproti předchozím teoriím posun $\mathrm{v}$ problematice zahrnutí dynamických, spouštěcích faktorů působících na výskyt $\mathrm{VoP}(\mathrm{StP})$.

\section{d. Hypotézy o vlivu konfliktu centrum-periferie na riziko převratu}

Vedle formy politického režimu je, jak již bylo zmíněno, dalším významným rysem státu jeho správní struktura. Z toho, zda má stát jednotnou (unitárnî), či naopak složenou (federace, konfederace, reálná unie atd.) strukturou, můžeme získat apriorní poznání o politické, ekonomické nebo sociální dynamice plynoucí z préedpokládaných konfliktních linií, které se na jejím utváření podílejí. Popis vnitřní strukturální diferenciace států na úrovni unitární/federativní však pro celkovou analýzu nestačí. Tím, že do tohoto popisu zahrneme i autonomní oblasti či další jednotky vzniklé procesem decentralizace či na základě nedokončeného vývoje budování moderního centralizovaného státu, jako jsou např́íklad samosprávní celky různých stupňů, otevřeme cestu k rozsáhlejšímu empirickému zkoumání odlišností mezi vnitrostátními územními celky (či vágněji oblastmi), které stojí v pozadí pravděpodobného formování konfliktu centrum-periferie.

Poměr mezi politickým (popř. ekonomickým) centrem státu a jeho okrajovou částí, nabývající podoby vzájemných interakcí a střetávání zájmů pramenících z jejich rozdílnosti, je u některých badatelů fundamentálním strukturálním faktorem, který se značnou měrou podílí na motivování (resp. demotivovánî) potenciálních strůjců VoP. Popis správní struktury státu pak posloužili k formulaci hypotéz o vlivu konfliktu centrum-periferie na riziko převratu.

Tento prýstup k výzkumu VoP, který pracuje s hypotézou vztahu mezi správní decentralizací (resp. heterogenizací centra a periferie) a poklesem rizika převratu, má v odborné literatuře dvě modifikované verze. Badatelská dvojice R. Jia a P. Liang ve svých pracích (2012a, 2012b) předkládá hypotézu týkající se příčinné vazby VoP na míru decentralizace převratem postiženého státu. Podle jejich modelu jsou totiž př́padní konspirátoři nuceni zahrnout do svých plánů i reakci představitelů lokálních vlád, přičemž se vzrůstajícími pravomocemi a reálnou mocí těchto nižších správních stupňu se zvyšuje i pravděpodobnost aktivního odporu proti převratu v politickém centru. Disponují-li lokální vlády významnými ekonomickými a sociálními zdroji, má tato skutečnost rovněž negativní dopad na následné setrvání popřevratových elit u moci (Jia a Liang 2012a: 2-3). 


\section{Schéma 3: Časový model vojenského převratu se zapojením vlád na místní úrovni}

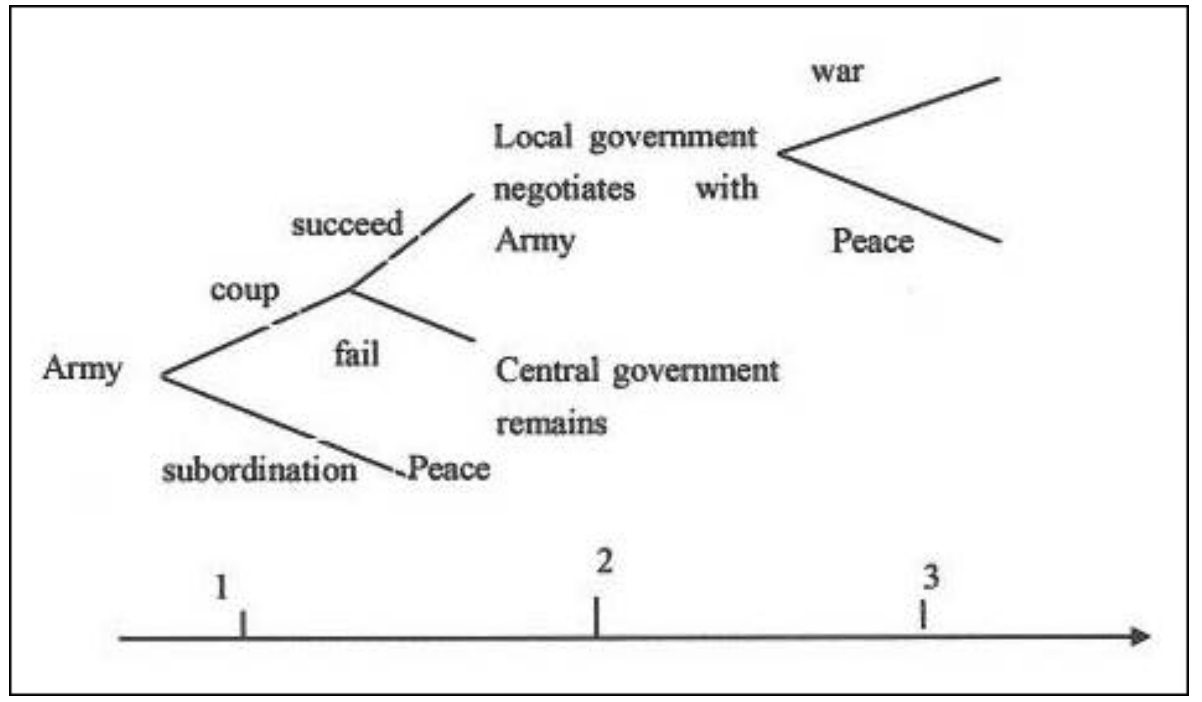

Zdroj: Jia, Liang 2012a: 20.

Způsob, jakým může decentralizace klást překážky uskutečnění převratu a tím i demotivovat jeho prrípadné strůjce ve fázi samotných úvah o VoP, lze odvodit z časového Jia-Liangova modelu (viz schéma 3). V centralizovaném státě, tedy takovém, $\mathrm{v}$ němž jsou fundamentální zdroje kumulace a uplatňování moci (finanční zdroje, ozbrojené síly a další bezpečnostní složky, prostředky řízení zahraniční politiky) koncentrovány do jednoho politického centra, bývá obecného cíle převratu dosaženo ovládnutím právě jediného mocenského ústředí. Oproti tomu převedení části těchto mocenských zdrojů na nižší, lokální či regionální stupně vládnutí staví při přípravě $\mathrm{VoP}$ armádu před problém, kdy svržením centrální vlády není dokonáno převzetí kontroly nad státem jako celkem. Odpor politické reprezentace periferie proti uzurpátorům totiž může vyústit až v rozpoutání občanské války, jejíž vypuknutí je v př́krém rozporu s cílem jakéhokoli převratu.

Schopnost lokálních politických aktérů zabránit armádě v provedení VoP je strukturálním faktorem, který př́znivě působí na odolnost režimu vůči takovýmto náhlým protiústavním změnám. Nicméně potřebná moc, nebo spíše politická vưle regionálních aktérů uplatnitelná ve vztahu k mocenskému centru státu, se v pojetí druhé hypotézy o vlivu decentralizace na riziko převratu zdá být pouze intervenující proměnnou. Tato druhá perspektiva, jejímuž ověrování věnuje badatelskou pozornost např́klad M. Lissak, totiž dosazuje do vzorce VoP na místo nezávislé proměnné nominální veličiny (a) „síla centra“ a (b) „odlišnost periferie“ (Lissak 1973: 61). Jejich různé kombinace pak různou měrou ovlivňují zranitelnost režimu.

Dvě proměnné o dvou možných hodnotách dávají vzniknout skupině čtyř typů státu (A-D) definovaných dle parametrů centra a periferie (viz schéma 4). $Z$ této skupiny je vůči převratu nezranitelnějším státem typ $B$, vyznačující se 
„slabým národním, politickým a sociálním centrem“ a „výrazně se lišící periferii““. Taková kombinace vytvář́ „strukturu přeplněnou př́ležitostmi pro kolaps celého společenského systému“ (tamtéž: 61-62). Signifikantní protichůdnost zájmů centra a periferie je $\mathrm{v}$ tomto př́padě navíc umocňována slabostí centra, které není schopno čelit své mocenské degradaci plynoucí ze vzájemných sporů. Státy kategorizované jako $\mathrm{C}$ a $\mathrm{D}$ budou oproti tomu čelit poměrně malému sociopolitickému pnutí uvnitř svých společností, jež, a to zejména u typu C, nemá dostatečnou destruktivní sílu.

Schéma 4: Matice o čtyřech typech státu definovaných sílou jejich politického centra a mírou odlišnosti jejich periferie

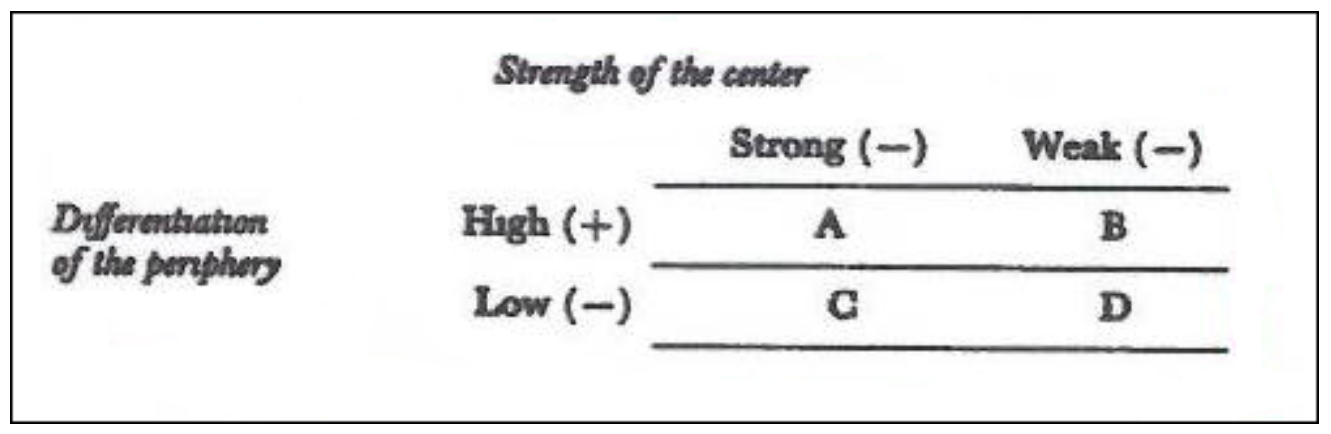

Zdroj: Lissak 1973: 61.

Jedná se o další z koncepcí zahrnujících strukturální faktory, které vyplývají z podoby daného politického systému. Heuristický př́istup k možným důsledkům vlivu štěpné linie mezi politických centrem a politickou periferií na stabilitu režimu doplňuje předešlé teoretizace, čímž instrumentár badatele problematiky VoP již zahrnuje holistický, tak i partikulární pohled na charakter státu, vycházejíce z kategorizace Z. Baranyho. ${ }^{11}$ Pro dosažení komplexní percepce př́čin převratu však zbývá do instrumentáře zakomponovat teorii o vlivu sociální stratifikace společnosti, mezinárodního bezpečnostního prostředí nebo historické zkušenosti. Hypotézy o konfliktu centrum-periferie nepředkládají odpověd’ na možné dopady socioekonomických podmínek na bezpečnostní prostředí státu.

11 Z. Barany ve svém článku Armies and Revolutions podrobněji popisuje jednotlivé nezávislé proměnné, které je z pohledu analytika potřeba $\mathrm{v}$ hodnocení budoucího jednání ozbrojených sil brát v potaz. Tyto okolnosti (,influences") zasazuje dle původu jejich vzniku do čtyř kategorií: s kořeny v armádě samotné, ve vládnoucím režimu, ve společnosti a v zahraničí. Nutno podotknout, že pojem „revoluce“ Barany ve svém př́spěvku dále nespecifikuje a z kontextu vyplývá, že za ni pokládá každý státní převrat, na jehož výsledku se podílejí protesty obyvatelstva (srovnej pojem revolučního převratu v Martinák 2015: 109-110), popř. dochází k lidovému povstání vůči režimu. Pro naše potřeby jsou tudíž Baranyho závěry koncepčně relevantní. 


\section{e. Obecná teorie legitimity a koncept vakua}

Všechny teoretické prŕstupy, které byly doposud v textu popsány a zváženy dle své relevance, měly přes svou různorodost něco společného. Teorie vojenské dostřednosti, teorie protiváhy i hypotézy o vlivu odlišných forem režimu či konfliktní linie centrum-periferie na výskyt $\operatorname{VoP}(\mathrm{StP})$ pokládají za fundamentální nezávislé proměnné vybrané strukturální faktory. Jejich autoři a uživatelé se pokouší vysvětlit proces formování takového společenského prostředí, jež nabízí vhodné podmínky pro plánování a uskutečnění převratu. Takové prostředí je sice nutnou podmínkou pro existenci $\operatorname{VoP}(\mathrm{StP})$, nebo alespoň pokus o něj, avšak není postačující k pochopení dynamiky politického, ekonomického i bezpečnostního prostředí, $\mathrm{v}$ jejichž komplexních příčinných vazbách se mnohdy nachází spouštěcí impuls pro zahájení převratu. S nápravou tohoto nedostatku přicházejí studie, které kladou důraz na spouštěcí potenciál faktorů s delegitimizačním efektem na vládnoucí režim.

Legitimita je jednou z nejužívanějších politologických (sociologických) abstrakcí, která se pro odbornou i laickou veřejnost stala základní interpretační pomůckou, díky níž lze popsat problematiku delegování moci mezi politickou elitou a masou. Bez ohledu na její zdroje, které Max Weber (1978: 215-145) popsal ve své typologii „tř́ čistých typů autority“, je legitimita definovatelná coby víra v oprávněnost nadvlády a „systému nadvlády“ (tamtéž: 214). Při jejím posuzování je potřeba vycházet z několika skutečností, které J. Clark (2007: 143) shrnul do tří bodů: (1) legitimita je psychologickým, nikoli právním fenoménem - slovy R. Krause je jistým druhem „iluze veřejnosti““ (cit. v Johnstad 2012: 518). Ze své podstaty je neuzákonitelná, nikterak ustanovitelná; vždy vyplývá z momentálních nálad veřejnosti, která reaguje na aktuální stav svých životních podmínek a neformálně hodnotí jejich přijatelnost (Clark 2007: 143).

Z tohoto poznání částečně plyne další specifikum legitimity: (2) závislost na kontextu. Již zmíněné životní podmínky bývají často redukovány na pouhý bezpečnostní stav, tedy hlavní funkční oblast státu, popř. jedinou působnost státu minimálního. Ač ji lze považovat za klíčovou, není jedinou hybnou veličinou legitimity. P. Johnstad ve své studii kauzality mezi legitimitou a politickou stabilitou režimu předkládá čtveřici sekundárních zdrojů, které zpravidla ospravedlňují postavení vládnoucí elity: Jsou jimi „politická mytologie“ (soustava společenských norem a politické tradice utvárející iluzi nezvratnosti mechanismu politického systému, jímž je elita dosazována do vládnoucích pozic - dědičné právo, volby, aj.), „výkonnost“ (vládou dosažené výsledky, jež pozitivně působí na její vnímání obyvatelstvem), „mezinárodní podpora“ (externí legitimita politického, vojenského, ekonomického, ale také kulturního či ideologického původu) a existence hrozby či její „iluze“ (vyvěrající jak z vnitřního společenského štěpení, tak z vnějšího bezpečnostního prostředî) (Johnstad 2012: 519-522). 
Posledním důležitým aspektem legitimity je (3) její relativnost. Absolutní legitimita režimu - uznání vlády veskrze celým obyvatelstvem - je nereálná a pro vládu hodnocenou jako legitimní není ani nezbytná. Na druhou stranu vládnoucí režim zpravidla zcela nepostrádá legitimitu ani během období krize (povstání části vlastní populace či občanské války), ačkoli ta bývá za těchto podmínek značně otřesena. Pro zjednodušení lze považovat konkrétní politický režim za v očích vlastních obyvatel legitimní, pokud jeho vládu uznává relativní většina populace žijící na jí spravovaném teritoriu.

Při přijetí poslední ze zmíněných premis se však okamžitě nabízí otázky: Jakou podobu na sebe bere toto uznání? Co vlastně obnáší v odlišném strukturálním nastavení různých forem politického režimu? Legitimita, jak ji vnímá M. Weber, může být různého charakteru v závislosti na jejím původu a způsobu její demonstrace - nebo možná lépe, na způsobu „udělování“. Její operacionalizace pro potřeby definice veličiny a dosazení její hodnoty tak vyžaduje preciznější př́stup.

Definice legitimity vlády ve státech s demokratickou formou vlády je nasnadě: Vláda je legitimní, pokud byla zvolena ve svobodných volbách konaných v časových intervalech nepřekračujících běžnou dobu funkčního období vlády (sedm let - některé prezidentské systémy upřednostňují politickou stabilitu zajišt'ovanou delším funkčním obdobím hlavy státu/vlády, jako například Francie před rokem 2000). Přízeň elektorátu je ovšem mnohem proměnlivějěśí, nežli dokáže mechanismus pravidelně konaných voleb reflektovat. Jak ukazuje teorie volebních cyklů, ${ }^{12}$ voličská podpora vládnoucí elitě (politické straně či koalici stran) se v průběhu jejího funkčního období mění - s takřka železnou pravidelností dojde k jejímu alespoň dočasnému snížení. Proto je při hodnocení okamžité úrovně uznání vlády obyvatelstvem potřeba vycházet z momentálních nálad voličstva. Nicméně diskuze nad legitimitou $v$ demokratickém režimu $v$ našem př́padě ztrácí ve světle malé pravděpodobnosti výskytu $\mathrm{VoP}$ (viz výše) na významu.

V nedemokratických režimech je posuzování legitimity vlády poněkud složitější. Zatímco normativní soud nad legitimitou nedemokraticky dosazené či autokraticky vládnoucí elity by byl, zejména z lidskoprávního pohledu, jednoznačně odsuzující, pozitivistická perspektiva prripouští situaci, v níž autokratická vláda může oprrít svůj nárok o aktivní nebo pasivní podporu mas. Koncepční odpovědí na tento problém je teorie „mocenského vakua“.

Podobně jako na úrovni mezinárodního politického systému ${ }^{13}$ může také ve vnitrostátní politice mocenské vakuum pomoci vysvětlit, proč armáda za určitých okolností intervenuje do politiky cestou VoP. Vakuum je prázdný prostor, do

\footnotetext{
12 Teorie volebních cyklů (více viz například Šaradín 2008) nabízí vysvětlení proměnlivost voličských preferencí resp. podpory elektorátu vládním politickým stranám v průběhu volebního období. Vládní strany ztrácí oblibu voličů na počátku svého vládního angažmá z důvodu prosazování nepopulární politické agendy, zatímco v závěrečné etapě se jejich preference zvedají díky méně kontroverzní politice nesoucí z důvodu blížících se voleb zřetelné znaky populismu.

${ }^{13}$ Pro podrobnosti k mocenskému vakuu v mezinárodní aréně viz Martinák 2011.
} 
kterého vlivem tlaku expanduje prostor okolní. Rovněž mocenské vakuum se vyznačuje prázdnotou způsobenou mocenskou marginalizací státního subjektu, nominálního suveréna $\mathrm{v}$ daném prostoru. Jestliže výkonné složky státu pod vedením politické elity nejsou schopny plnit své funkce při kontrole a správě území, jiní vnitropolitičtí aktéři disponující vlastními mocenskými kapacitami (donucovacími prostředky) mohou využít této príležitosti $\mathrm{k}$ uplatnění a zvýšení vlastní moci (Ben-Eliezer 1998: 313).

V tomto pojetí se však nejedná o vakuum celosystémové, které by podněcovalo vnější (zahraničnî) subjekty ke vstupu do politického systému a zaujetí pozice jeho organické součásti. Ačkoli mocenské vakuum na vnitrostátní úrovni sice může být zaplněno nestátním aktérem pocházejícím z vnějšku systému (což je vhledem $\mathrm{k}$ zmíněné nutné disponibilitě mocenskými kapacitami nepravděpodobné), nelze vyloučit, že se stane cílem systémového subjektu, kterým je např́lklad armáda. Toto vnímání mocenského vakua (Thompson 1975: 466-467) zahrnuje představu politického systému jakožto nedělitelného celku, obklopeného subjekty nepodílejícími se na jeho vnitřním mechanismu (rozhodovacím procesu). Při posuzování zranitelnosti režimu vůči převratu je ale potřeba zahrnout i vývoj vztahů mezi systémovými subjekty, obzvláště ze sféry civilně-vojenských vztahů.

Stručně řečeno, mocenské vakuum je důsledkem delegitimizace vládnoucí elity, k níž dochází ztrátou legitimizačních zdrojů, jak je předložil P. Johnstad (viz výše). Nejvhodnějším indikátorem této delegitimizace je přítomnost různých podob lidového odporu vůči vládě - masové demonstrace za odstoupení vlády, srážky účastníků protestních hnutí s bezpečnostními složkami, ozbrojený odpor -, které souhrnně přispívají $\mathrm{k}$ degradaci bezpečnostního prostředí. Hobbesovský leviatan, garant stability a ochrany před násilím prrirozeného stavu, tím ztrácí důvod další existence.

\section{Schéma 5: Schématický model legitimizace politické režimu}

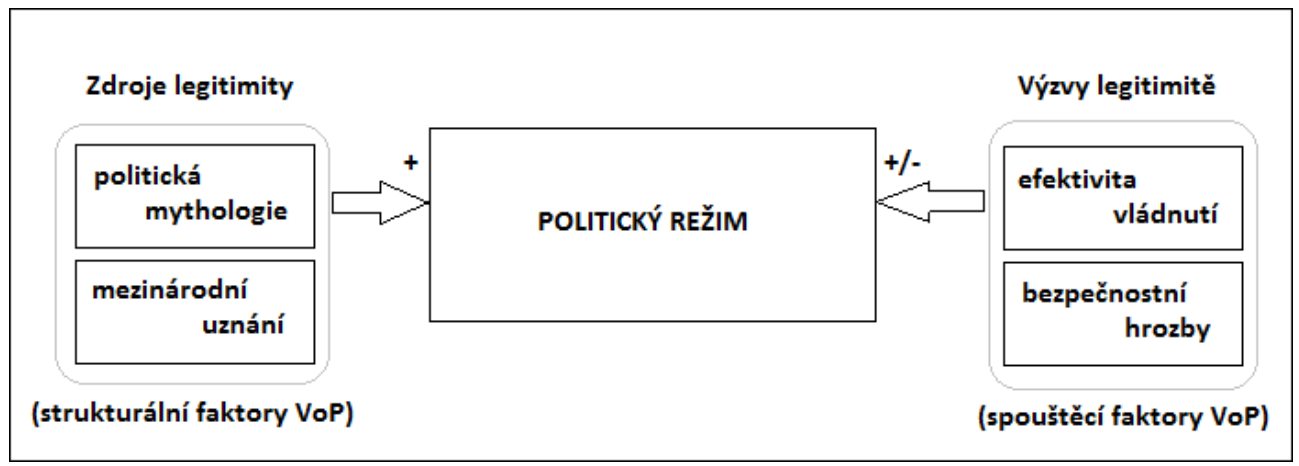

Zdroj: autor. 
Zatímco zdroje (viz schéma 5) spoluutvářejí politický systém a dodávají mu větší či menší míru legitimity, její formu a rozsah, v němž se aktuální úroveň legitimity může $\mathrm{v}$ rámci systému pohybovat, výzvy vznikají z dynamiky vnitropolitické scény a přispívají $\mathrm{k}$ legitimitě (např́klad dobrá výkonnost státního aparátu, dobrá bezpečnostní situace), či naopak vládnoucí režim delegitimizují (např́lklad nevýkonnost, bezpečnostní hrozby). Zejména pod položku „efektivita vládnutíi lze zahrnout mnoho faktorů, které mohou oslabovat režim a souběžně s tím zvyšovat i jeho zranitelnost vioči převratu. Ty vyvěrají z vývoje sociálního a ekonomického prostředí.

\section{f. Teorie etnického antagonismu: změna mocenského postavení}

Teorie vojenské dostřednosti a teorie protiváhy zdůrazňují etnické složení obyvatelstva státu, v němž hrozí vznik VoP, a pracují s ním jako s dílčím faktorem doplňujícím příčinný účinek fundamentů (finanční/materiální zabezpečení potřeb armády, resp. systémové nástroje kontroly ozbrojených sil). V rámci studií převratů se vyprofiloval teoretický prýstup, který posuzuje mezietnické vztahy v rámci sociální struktury jakožto faktor ústřední. Etnický antagonismus je tak z pohledu autorů upřednostňujících tuto koncepci hlavní příćinou VoP.

Teorie etnického antagonismus bývá nejčastěji využívána při výzkumu států subsaharské Afriky, v nichž má etnická kompozice obyvatelstva stále signifikantní vliv na politické a bezpečnostní klima. Jak upozorňuje např́klad P. Roessler, pro tyto země je typický postkoloniální společenský vývoj, přičemž právě etnický antagonismus je důležitým dědictvím koloniální správy (2011: 304). Rozdělení dle etnických linií a posilování kolektivních identit „přirozených vůdcủ“ a „přirozených poddaných" bylo rozšířeným způsobem řízení domorodé populace (př́íkladem par excellence byly belgické kolonie v Africe). Žrejmě nezamýšleným důsledkem pak je po generace zakořeněné opovržení na straně upřednostňovaných a nenávist na straně upozaděných. Avšak konfliktní povaha mezietnických vztahů je hybnou silou nejen $\mathrm{v}$ afrických zemích, nýbrž je vlastní všem multietnickým společnostem světa.

Otázkou tedy zůstává, jak rozpoznat jednotlivé faktory (a míru jejich působení), jež vedou $\mathrm{k}$ vyhrocení této pruirozené konfliktnosti zájmů rozdílných etnik do podoby „nemoci“ oslabující společenský organismus - tedy soudržnost společnosti a tím i její politický konsensus. Odpověd' se podle L. Cedermana, A. Wimmera a B. Mina - výzkumníků v oblasti teorií etnického konfliktu - skrývá $\mathrm{v}$ rozdílech $\mathrm{v}$ prístupu jednotlivých etnik k politické moci. Na základě jejich kódování následně sestavili kategorie etnik definovaných dle jejich podílu na procesu politického rozhodování: 1) disponující absolutní mocí (dále subkategorizováno na „monopol“ a „dominanci“), 2) dělící se o moc (bud’to v pozici „senior partner" nebo „junior partner"), 3) vyloučené z príistupu k centrální moci („,podílející se na správě regionální autonomie“, „projevující se 
separatistickými tendencemi“, „bez politického vlivu“ a „diskriminované“) (Cederman, Wimmer a Min 2010: 100-101). Každá kategorie a její subkategorie v tomto výčtu je dále sestupně diferencována dle participace na politické moci. Závěrem výzkumu uvedené trojice badatelů je indikace zvýšené pravděpodobnosti násilného aktu ze strany etnika zařaditelného do intervalu od ,junior partner“ až po „diskriminované“" které bylo zároveň v průběhu posledních dvou let degradováno z postavení charakterizovatelného v termínech „monopolu“ až ,senior partnera“.

Pokud mocenská degradace zvyšuje pravděpodobnost násilného aktu ze strany degradované etnické skupiny, zvyšuje se současně i riziko převratu, nebot' StP bezesporu patř́ mezi takové projevy. Většina autorů studujících dopad etnické skladby na vznik převratu však dává přednost - zřejmě $z$ důvodu převahy kvantitativního výzkumu - jednodušším indikátorům, které J. Jenkins a A. Kposowa koncepčně sdružili do tří hlavních skupin: Zdůrazňující etnickou diverzitu (teorie etnické plurality), vyzdvihující etnickou konkurenceschopnost (teorie etnické soutěže) a zaměřující se na rovnováhu sil (teorie etnické dominance) (Kposowa a Jenkins 1990: 866-867; 1993: 131-132). Tato pojetí vycházejí nikoli $\mathrm{z}$ proměnnosti mocenské pozice etnika $\mathrm{v}$ rámci politického systému a změny v tomto postavení, nýbrž ze statického a dlouhotrvajícího charakteru etnického složení převratem ohrožené země.

První z Kposowou a Jenkinsem uvažovaných teorií tvrdí, že riziko převratu se zprostředkovaně zvyšuje kvưli velkému počtu etnik obývajících území daného státu. Vysoký stupeň etnické heterogenity zaprríčiňuje menší schopnost politických aktérů uzavírat politické koalice, jež právě $\mathrm{v}$ takovém prostředí získávají na důležitosti (Rabushka a Shepsle 1972), a vede tak i k nejistému postavení politických elit a nenaplnění očekávání mas (Morrison a Stevenson 1972a, 1972b; McGowan 1975). Podstatou druhé teorie je př̀esvědčení o negativních dopadech prrítomnosti minimálně dvou vzájemně mocensky paritních etnických skupin, prričemž jedna pro druhou znamená politického konkurenta, a tedy i hrozbu jejich mocenským aspiracím. Čím vyváženější tyto dvě skupiny v přístupu ke zdrojům a v kvantitativních parametrech jsou, tím je nebezpečí jejich střetu vyšší (Korpi 1974; Horowitz 1985). Konečně třetí teorie klade důraz na koncentraci moci v rukách jediného etnika. Takto vzniklá dominance je nutně doprovázena vyloučením zbylých skupin z nejvyšších mocenských postů, což přirozeně podněcuje jejich odpor a vede $\mathrm{k}$ destabilizaci bezpečnostního prostředí (Jackman 1978; Brass 1985). 
Schéma 6: Kauzální model teorie etnického antagonismu

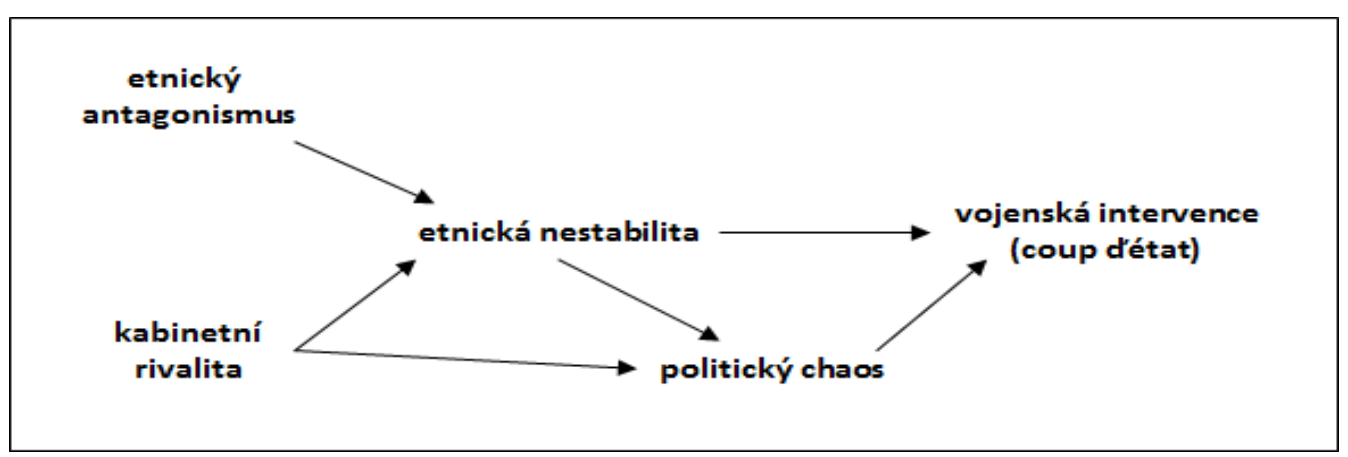

Zdroj: autor (modifikované schéma dle Kposowa a Jenkins 1993: 141).

Ze statistického výzkumu, v němž Kposowa a Jenkins (1993: 141) sledovali kauzální efekt mezi, inter alia, etnickou diverzitou, konkurenceschopností a dominancí coby nezávislými proměnnými a prítomností VoP jakožto proměnnou závislou, vyplývá, že existence dominantního etnika ve společnosti má (na rozdíl od prvních dvou jmenovaných) na odolnost politického režimu vůči převratu příznivé účinky. Diverzita a konkurence oproti tomu zvyšují pravděpodobnost VoP př́mo tím, že vyvolávají konflikty uvnitř politických a vojenských elit, a nepř́mo (viz schéma 6), pokud způsobují všeobecný politický chaos, na který mohou ozbrojené síly reagovat převzetím výkonné moci (tamtéž: 141-142).

\section{g. Politicko-ekonomický př́stup ve výzkumu státního převratu}

Celá řada badatelů hledá príčinnou vazbu mezi VoP (StP) a strukturálními faktory bez ucelené teoretické konstrukce, jejíž premisy a předpoklady by aplikovali. Někteří z nich (především anglosaské provenience) tak sdílí zaměření na proměnné ekonomické povahy, tedy volbu prrístupu $\mathrm{k}$ výzkumu převratu založeného na metodách politické ekonomie. Ačkoli je tato oblast výzkumu u anglicky píšících autorů velmi oblíbená, postrádá jasně formulovanou teorii, protože vychází $z$ převážně $z$ kvantitativních přehledů různých socioekonomických ukazatelů a sledování jejich kauzálního efektu na pravděpodobnost vzniku VoP (StP). Principiální hypotéza tohoto př́stupu - ekonomická krize způsobuje politickou nestabilitu - totiž žádné vyjádření ve formě sofistikované teorie nevyžaduje.

Obdobně jako u teorie etnického antagonismu je i vliv neuspokojivé ekonomické situace na zhoršení bezpečnostního prostředí a tím i riziko VoP (popř. jiných bezpečnostně-patologických jevů) dvojí podoby: Přímý, neboli mající původ v obraně socioekonomických zájmů armády, a nepřímý, tedy zprostř̌edkovaný politickým chaosem (political turmoi). První pojetí předpokládá ohrožení ekonomických zájmů vojenských elit i řadových př́slušníků silových složek, které může vyvolat potřebu politické změny a normalizace poměrů v zemi rozjitřené hospodářskými problémy. Taková potřeba může být dále násobena politickým 
spojenectvím armády a velkokapitálu, přičemž podobná kooperace je typická zejména pro období hospodářských transformací, kdy reformní politika vlády ohrožuje životní jistoty vojáků a majetek byznysmenů. K odstranění hrozby se jim, mimo jiné, nabízí VoP následovaný nastolením politického režimu vyznačujícím se protekcionismem národního hospodářství, odporem vưči zahraničnímu kapitálu a technokratickým, od ideologie oproštěným výkonem vlády - často samozřejmě provázeným vyloučením veřejnosti z politického procesu (Casper 1991: 194).

Druhé pojetí - nepř́ímá projekce ekonomické krize do zranitelnosti režimu zasazuje do vzorce intervenující proměnnou: politickou destabilizaci. Jedná se nejen o krizi na úrovni režimních elit a vyhrocení vztahu mezi vládou a politickou či vojenskou opozicí, ale především o nepokoje v celospolečenském měřítku. Masy nespokojené se špatnými socioekonomickými podmínkami, mnohdy provázenými jejich politickou marginalizací a velkou korupcí byrokratického systému, požadují změnu ve vedení země, čímž motivují armádu k provedení této změny (viz schéma 7). Kauzální zákonitosti dopadů ekonomické krize jsou přitom nápadně podobné kauzálnímu modelu teorie etnického antagonismu, což ovšem není nijak zvlášt' překvapivé (srovnej schémata 6 a 7).

Schéma 7: Kauzální model dopadů ekonomické krize na výskyt vojenských převratů

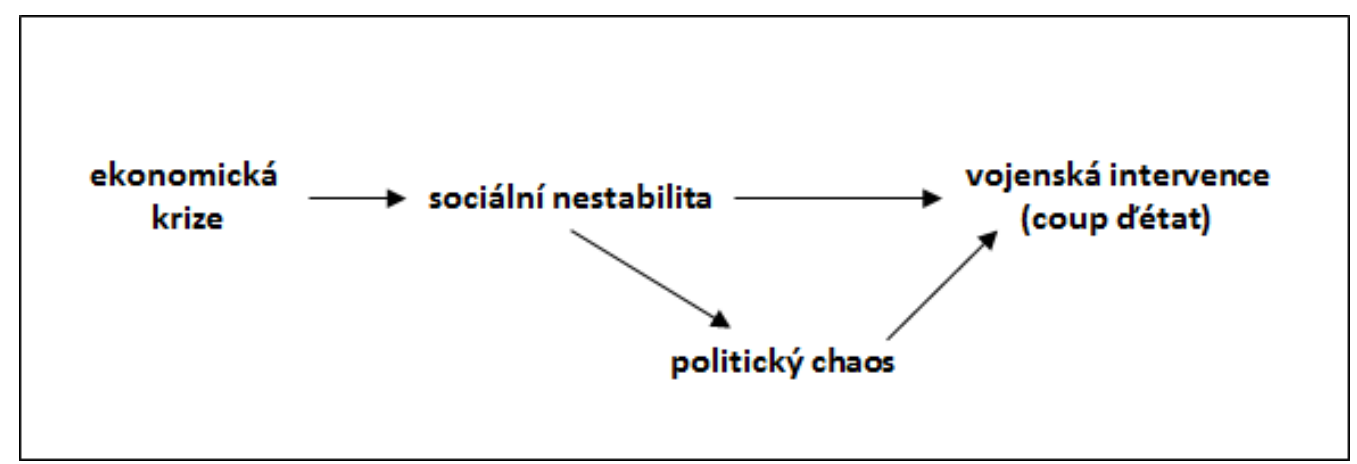

Zdroj: autor.

Jako indikátory ekonomické krize volí autoři hledající její př́čcinný dopad na vznik StP běžně užívané makroekonomické ukazatele hospodářské kondice. Patří mezi ně meziroční změna hrubého domácího nebo národního produktu (Wells a Pollnac 1988), hodnota HDP přepočítaná na hlavu (Putnam 1967; Ades a Chua 1997), index lidského rozvoje (HDI; McGowan 2005), ale také parciální ukazatele vyjadřující strukturu nezaměstnanosti $\mathrm{v}$ zemědělském či průmyslovém odvětví ekonomiky (Putnam 1967; Wells a Pollnac 1988) nebo podíl exportu na celkové produkci hospodáršství (O’Kane 1993). Zatímco první tři indikátory vypovídají o povšechné socioekonomické situaci obyvatelstva (zejména pak HDI) a tím i o potenciální nespokojenosti s vládou a radikalizaci ve volbě možných řešení 
neutěšeného stavu - tedy o strukturálních faktorech -, zbylé dva mohou odhalit existenci faktorů motivačních. Vysoká míra zaměstnanosti v agrárním sektoru a exportní zaměření ekonomiky tvoří překážky, s nimiž strůjci převratu musí ve svých úvahách počítat a dobu jeho realizace tomu přizpůsobit. Rurální populace se vyznačuje spíše konzervativním smýšlením a loajálním postojem k vládnoucímu establishmentu, z čehož může pramenit její případná negativní reakce na převrat ve vnitropolitické oblasti. $\mathrm{V}$ prípadě exportně zaměřené ekonomiky musí konspirátoři zvážit zahraničněpolitickou reakci, kdy možný úspěšný převrat může mít za následek mezinárodní embargo se zničujícími dopady pro hospodářství převratem stiženého státu.

\section{h. Teorie nákazy: šíření bezpečnostní nestability}

Oproti ostatním zde předloženým teoretickým př́stupům se řada badatelů (např́lklad Wells 1974; Agyeman-Duah 1990; Iqbal a Starr 2008; Rittinger a Cleary 2013) ve svých snahách o pochopení kauzálních vztahů a vytvoření explanačních konstrukcí VoP (StP) zaměřuje na zcela odlišný typ nezávislých proměnných faktorů, jejichž původ lze vysledovat vně předmětného státu. Již z názvu, jímž mnozí z nich souhrnně označují způsob projevu jimi preferované veličiny, totiž „nákaza“ (Wells 1974: 873; Agyeman-Duah 1990: 550; Lunde 1991: 15; Iqbal a Starr 2008: 318; Barany 2011: 25), je zréjmé, že v centru zájmu tohoto badatelského př́stupu je proces projekce nepříznivých regionálních jevi̊ na bezpečnostní (vlastně celospolečenské) prostředí uvnitř hranic daného státu. Jak ovšem někteři autoři upozorňují (např́klad Levitsky a Way 2006; Rittinger a Cleary 2013), mezinárodní politický systém může mít na vnitropolitickou situaci i pozitivní vliv.

Z. Iqbal a H. Starr, kteří se zaměřili na studium příčin, průběhu a důsledků rozpadu státních struktur, ve svých studiích nejprve identifikovali a kategorizovali hlavní destabilizační faktory, jež vedou k selhání státu (state failure): Jsou jimi „politická nestabilita“, „nepokoje“, „,mezinárodní konflikt" a „občanská válka“, a to ve vzestupném pořadí dle pravděpodobnosti, s níž mohou vyústit v rozpad státu (Iqbal a Starr 2007: 13-14). Poté pozornost přesunuli k rozpadu státu a degradaci bezpečnostního prostředí z pohledu jeho dopadů navenek. Negativní vlivy procesu imploze státní struktury, ${ }^{14}$ akcelerované čtyřmi výše zmíněnými skupinami faktorů, se dále šírí mezinárodní arénou a jako nákaza nejprve dopadají na státy bezprostř̌edně sousedící se zemí prvotního výskytu, posléze i na státy hraničící se sekundárně napadenými zeměmi. I když samotné selhání státu není dle dvojice této

\footnotetext{
14 Pozornost si zaslouží především role státního převratu, kterou mu Iqbal se Starrem ve svém výzkumu přisuzují. StP je v jejich modelu jedním z činitelů destabilizace a následného rozpadu státu. Takové pojetí potom prrirozeně vede ke kauzální smyčce, v níž příčina (úspěšný StP) je zároveň důsledkem procesu, který vyvolává nebo k němu alespoň výrazně přispívá. Tento předpoklad koresponduje s teorií pasti převratu (viz níže).
} 
výzkumníků „nakažlivé“ (2008: 328), patologické jevy bezpečnostního prostředí (mezi něž řadí i StP), které jsou současně průvodními jevy rozpadu státu, nosí prokazatelnou tendenci šírit se mezi jednotlivými státními aktéry mezinárodního politického systému. Jak upozorňuje Z. Barany, šíření může nabýt podoby destabilizační vlny, která je částečně odbornou, ale obzvláště laickou veřejností opatřována adjektivem „revoluční“ (2011: 25) a prostřednictvím níž se, snad s výjimkou mezinárodního konfliktu (který však také může vypuknout jako reakce na mezinárodní krizi zapř́ćčněnou „revoluční vlnou“), šírí všechny destabilizační jevy tak, jak je popsali oba badatelé (tedy i včetně StP). Pravděpodobnost bezpečnostní destabilizace konkrétního státu je přitom udávána dvěma činiteli: geografickou vzdáleností (nejzranitelnější jsou pochopitelně bezprostředně sousedící státy) a závažností průvodního jevu destabilizace (nejčastěji se mezi státy šírí občanská válka, naopak politická nestabilita, vyznačující se nízkou intenzitou, spíše zř́íka) (Iqbal a Starr 2008: 328-329).

Jestliže si odmyslíme občanské války, zejména $\mathrm{v}$ druhé polovině dvacátého století sužující země třetího světa, a mezistátní konflikty, které sice mají značný destabilizační potenciál i pro nezainteresované státy válkou stiženého regionu, ale zároveň, jak správně podotýká B. Agyeman-Duah, mnohdy plní pro vládnoucí režim čelící krizi legitimity (viz výše) „sebezáchovnou“ funkci (1990: 549), představuje VoP (StP) z důvodu své poměrně vysoké nakažlivosti signifikantní hrozbu. Z této skutečnosti plynoucí př́ičinný účinek je koncepčně vyjádřen teorií nákazy vycházející z již výše popsaného trendu: „[P]ř́itomnost př́evratu $\mathrm{v}$ jedné zemi stimuluje vznik dalších převratů $\mathrm{v}$ jiných zemích, $\mathrm{v}$ prvé řadě těch sousedících“ (Wells 1974: 874).

Tato teorie se $\mathrm{v}$ anglosaské odborné literature stala velmi oblíbenou především $\mathrm{v}$ šedesátých až osmdesátých letech minulého století, kdy tvořila konzistentní symbiózu s rovněž populární a často aplikovanou teorií modernizace (Lunde 1991: 15), která představuje konkurenční př́istup k teorii přechodů (Gans-Morse 2004). ${ }^{15}$

K nákaze bezpečnostních hrozeb, které samy o sobě představují motivační faktor pro přípravu a realizaci VoP, se mnohdy přidává i řízená, za určitým politickým cílem plánovaná činnost ze strany cizích velmocí. Řízená finanční a materiální podpora armádě od jiného státu, doprovázená politickými zárukami neutrality při uskutečnění převratu či aposteriorního diplomatického uznání nové vlády po jeho úspěšném dokončení, nebo naopak provádění diverzních akcí ozbrojených jednotek na území cizího státu, jehož bezpečnostní prostředí má být úmyslně vyvráceno, jsou dostatečně silnými spouštěcími impulsy, které mohou vést k VoP (Wells 1974: 881-882). Tyto rozdílené vlivy - šsiření bezpečnostní

15 Kompatibilita teorie nákazy s teorií modernizace spočívá v průvodních jevech procesu normalizace role a pozice armády jakožto aktéra politického systému v modernizujících se rozvojových zemích. VoP, vnímaný v těchto zemích jako legitimní nástroj ozbrojených sil k zachování modernizačního rozvoje, je volbou pro obdobné skupiny „mladých důstojníkü“ při eliminaci „reakcionářských odchylek“" svých politických elit. 
destabilizace (včetně převratů), přímá vojenská podpora zvnějšku a aktivity cizí moci podrývající vnitropolitickou a bezpečnostní situaci - se pak spolupodílí na utváření vhodných podmínek pro provedení VoP (viz schéma 8).

\section{Schéma 8: Kauzální model státního převratu z perspektivy teorie nákazy}

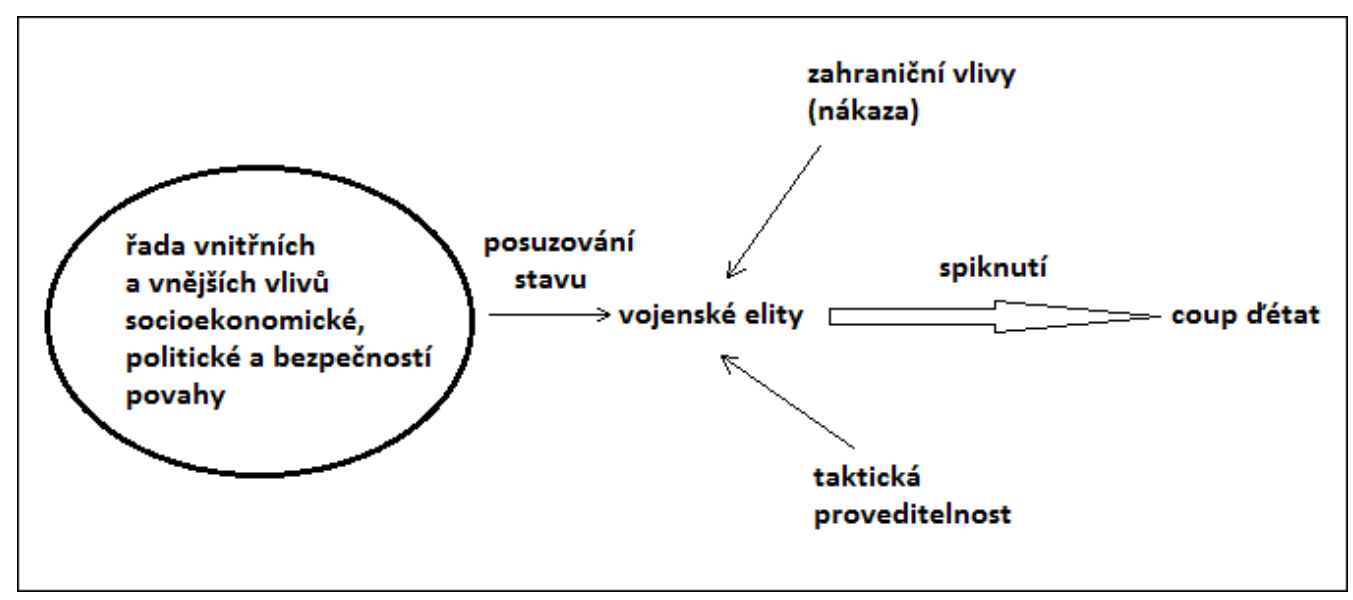

Zdroj: upraveno z Wells 1974: 885.

\section{i. Hypotéza pákového efektu a provázání}

Teorie nákazy (viz výše) je takřka intuitivně pochopitelnou konstrukcí, která ilustruje kauzální vazbu mezi bezpečnostním prostředím mezinárodního politického systému a výskytem bezpečnostně-patologických jevů, mezi něž patří i VoP (StP). Vyjadřuje však pouze omezenou perspektivu, nebot' vnější jevy nemají výhradně negativní vliv na vnitropolitickou stabilitu. $\mathrm{V}$ rámci teorie tak absentuje snaha vysvětlit konsekvence faktorů pocházejících ze zahraničí, mající za jistých podmínek posilující účinek na odolnost režimu vưči StP. Tuto konceptuální mezeru může zaplnit př́stup $\mathrm{k}$ výzkumu determinantů StP vycházející z premis teorie interdependence a racionální volby.

Jestliže vzájemná závislost státních aktérů operujících v mezinárodním prostředí skutečně ovlivňuje zahraniční politiku jednotlivých aktérů tak, že snižuje význam hard power prostředků při řešení mezistátních sporů, snižuje v důsledku počet a závažnost těchto konfliktů a působí preventivně proti násilným změnám v uspořádání mezinárodního politického systému. To vše skrze posilování interdependence států (více viz Keohane a Nye 1987), čímž nutně formuje rozhodování politických elit také na vnitropolitické úrovni. To se rovněž vztahuje i na ozbrojené síly, které musí reflektovat podmínky, v nichž plánují a rozvíjí svou činnost. Závěry studií zaměřených na výzkum př́znivých účinků mezinárodního prostředí na odolnost (vnitrostátního) politického režimu proti VoP (StP) lze v zásadě shrnout do dvou výkladů (Levitsky a Way 2005; Cleary 2006; Barracca 
2007; Rittinger a Cleary 2013), které definují kauzální vztah soft power nástrojů bud' politického, nebo ekonomického charakteru.

V rámci prvního je za klíčový faktor pokládán efekt (někdy až samovolného) prosazování se demokratických a liberálních hodnot spoluutvárejících takový politický režim, v němž je StP považován za nelegitimní způsob obměny politické elity (Arceneaux a Pion-Berlin 2007). Toto působení může nabývat podoby prrímého zasahování, kdy demokratické státy vyvíjejí zahraničněpolitický tlak s cílem iniciovat či akcelerovat proces demokratizace autokratického režimu, príčemž charakter podpory je závislý na interním prostředí objektu působení (Barracca 2007: 141), anebo nepřímé, vedlejší a samovolné tendence vyvolané integrací daného státu do politických, vojenských či ekonomických mezinárodních režimů, $\mathrm{v}$ jejichž rámci disponují liberálně-demokratické státy mocenskou převahou. ${ }^{16}$ Konceptuálním problémem tohoto výkladu je zejména fenomén demokratického převratu, jehož pravděpodobnost vzniku rozhodně nebude snižována vnějším demokratizačním tlakem - spíše naopak. Nesporným faktem ale je, že členství v nadnárodních celcích, jejichž prírozenou součástí je i snaha o různou míru politické integrace, je takřka zárukou prevence VoP. Se zvyšující se úrovní vzájemného politického provázání států se marginalizují možné mocenské zisky dosažitelné cestou převratu, čímž se snižuje i riziko jeho výskytu.

Druhý výklad je pro změnu založen na premise týkající se důsledků hospodářské spolupráce mezi zeměmi, kterou lze do značné míry považovat za průvodní jev globalizace. Oproti předchozímu př́stupu, kladoucímu důraz na „normativní sílu“ hodnotového řádu liberální demokracie, vychází tento výklad z racionálního posuzování rizik a přiležitostí: Uskutečnit $\operatorname{VoP}(\mathrm{StP})$ v zemi, která je navázána na světový (popř. regionálnî) trh prostřednictvím institucionalizace ekonomických vztahů na mezinárodní úrovni, by bylo iracionální (Remmer 1992: 17; Rittinger a Cleary 2013: 408). Nejenže by převrat zkomplikoval pozici státu na diplomatickém poli a měl by tak negativní vliv na vnitropolitickou legitimitu převratem dosazené politické elity a prípadné uznání ze strany mezinárodních aktérů, ale nepř́znivě by se projevil také v podobě možné ekonomické recese způsobené špatnou obchodní bilancí a zejména by zvýšil nebezpečí uvalení hospodářských sankcí (Levitsky a Way 2005: 21; Barracca 2007: 141; Rittinger a Cleary 2013: 408). Komplikací tohoto prústupu je dle E. Rittingera a M. Clearyho (2013: 408) historicky ověřená zranitelnost těch režimů, u nichž dosud nedošlo k socioekonomické transformaci společnosti vyvolané liberalizací národního hospodářství. Zatímco ekonomická integrace zvyšuje odolnost režimu vůči převratu, reformní (či revolučnî) přechod na globální liberalizovaný ekonomický systém naopak zvyšuje riziko převratu, nanejvýš však ve střednědobém horizontu

16 Je bezesporu diskutabilní, nakolik může politika „šî́enení demokracie“ v podání Západu nebo působení mezivládních organizací globálního významu přispět k upevňování demokracie ve světě. Př́kladem kontroverznosti této myšlenky je rozpad tradičních mocenských struktur v regionu Blízkého východu a severní Afriky, ke které zřetelně dochází od první poloviny roku 2011. 
(tedy po dobu trvání transformace - nelze ovšem vyloučit ani dlouhodobé trvání zvýšeného rizika převratu vinnou neúspěšné transformace).

Vyššího stupně konceptualizace dosáhli S. Levitsky a L. Way (2006: 382-388), kteři předložili modifikovanou hypotézu „pákového efektu a provázání (leverage and linkage). $\mathrm{Na}$ základě výsledků řady pŕṕpadových studií se soustředili na pochopení dynamiky vztahů mezi konkrétním státem, jež se stal dějištěm převratu, a hráči mezinárodní arény. Prostřednictvím diferenciace parametrů vzájemného působení (orientace, intenzita, původ) a typů politického režimu (demokracie, autokracie) dospěli k závěru, že tendence ke změně rizika převratu mủže nabývat nejen zcela odlišných hodnot, ale dokonce i opačné polarity.

Pákovým efektem (leverage), který přisuzují výhradně mocnostem Západu (Western leverage), pak rozumí „zranitelnost úřadujících vlád vůči vnějšímu demokratizačnímu tlaku“ (tamtéž: 382). Takovýchto „pák“, podmiňujících čerpání benefitů plynoucích z participace na mezinárodní spolupráci, je vícero: Členství v mezivládních a nadnárodních organizacích, materiální sankce, diplomatická izolace nebo vojenská intervence, popř. hrozba použití všech těchto zahraničněpolitických instrumentů. Pákový efekt, který mohou uplatnit (a často uplatňujî) státy Západu $\mathrm{k}$ dosažení svých národních zájmů a využití všech výhod, které skýtá jejich tzv. „oblast zájmu“ (EU a státy subsaharské Afriky, USA a Latinská Amerika, EU/USA a region MENA), je ovšem výrazně limitován trojicí činitelů geopolitické povahy. Prvním jsou subjektivní mocenské proporce státu, na něhož pákový efekt působí. Velké země, disponující dostatečně velkými vojenskými a ekonomickými kapacitami potřebnými k realizaci vlastní nezávislé zahraniční politiky, zastávají takovou geopolitickou pozici, která jim umožňuje tlaku Západu vzdorovat (tamtéž: 383). Druhým faktorem je existence mocnosti v daném regionu, která nesdílí západní zájem o prosazování demokratických hodnot a odpovídajícího modelu vlády a nabízí státu čelícímu pákovému efektu vojenskopolitickou a ekonomickou alternativu (Ruská federace a Společenství nezávislých států, Čína a státy jihovýchodní Asie). Třetím a posledním činitelem je upřednostnění zájmu o vnitropolitickou stabilitu předmětného státu nebo regionu před budováním tamního demokratického řádu. Během bezpečnostní destabilizace, způsobené např́klad destabilizační nákazou, bývají autokratické režimy ušetřeny pákového efektu z důvodu ochrany ekonomických zájmů zemí, které jinak pákový efekt využívají.

Zatímco pákový efekt si lze představit jako partikulární politiku, konceptuálně snadno uchopitelnou a rozpoznatelnou, provázání (linkage) je mnohem složitějším, víceúrovňovým, polysférickým fenoménem, jež můžeme chápat spíše coby přirozený, živelný důsledek globalizace. Levitsky a Way (tamtéž: 383) jej definují jako „hustotu vazeb a přeshraničních toků mezi předmětnými zeměmi a Spojenými státy, Evropskou unií a multilaterálními institucemi, při jejichž rozhodování hrají západní státy dominantní roli.“ Komplexnost provázání jakožto celospolečenského jevu a jeho rozsah, v němž účinně ovlivňuje jednání státu, je zřejmá z následujícího 
výčtu jeho variant: Geopolitická (naprŕklad participace ve vojenských spojeneckých blocích), sociální (např́iklad migrace, vznik diaspor, neboli tok osob), komunikační (tok informací, neboli př́stup ke globální internetové síti, vysílání západních televizních či rozhlasových stanic globálního záběru), transnacionální (např́íklad činnost církví či jiných nevládních organizací západního původu). Jak autoři zdůrazňují, síla a následný účinek všech typů provázání je nejvíce odvislá od geografické vzdálenosti objektu působení od center Západu, tedy USA a EU (tamtéž: 383-384).

Tabulka 2: Variační rozpětí demokratizačního tlaku při rozdílné intenzitě pákového efektu a provázání

\begin{tabular}{|l||l|l||}
\hline & \multicolumn{1}{|c|}{ velké provázání } & \multicolumn{1}{c|}{ malé provázání } \\
\hline \hline $\begin{array}{l}\text { silný pákový } \\
\text { efekt }\end{array}$ & $\begin{array}{l}\text { soudržný a efektivní } \\
\text { demokratizační tlak }\end{array}$ & $\begin{array}{l}\text { přerušovaný a omezený } \\
\text { demokratizační tlak }\end{array}$ \\
\hline $\begin{array}{l}\text { slabý pákový } \\
\text { efekt }\end{array}$ & $\begin{array}{l}\text { soudržný, avšak rozptýlený, } \\
\text { nepř́my demokratizační tlak }\end{array}$ & slabý vněǰ̌́i demokratizační tlak \\
\hline \hline
\end{tabular}

Zdroj: Levitsky, Way 2006: 388.

Paralelní působení „pákového efektu“ a „provázání“ násobí jejich jednotlivé dopady na legitimitu a tím i stabilitu politického režimu (viz tabulka 2). Uvalení ekonomických sankcí, účast na vojenské intervenci na území tř́tího státu, prrítomnost ve sfére vlivu regionální velmoci (pákový efekt) a členství ve vojenské alianci či mezivládních organizacích, napojení na mezinárodní obchod, který produkuje důležitou část prŕijmů státního rozpočtu, či rozvinutý turistický průmysl (provázánî) pak mohou bud' snižovat riziko převratu v př́padě demokratických režimů, anebo jej naopak zvyšovat u režimů autokratických.

\section{j. Teorie pasti převratu}

„Výskyt převratu v nedávné minulosti zvyšuje pravděpodobnost provedení dalšího převratu v budoucnosti.“ Takto lze zjednodušeně vyjádřit fundamentální motiv teorie pasti převratu (coup trap) (Zimmermann 1979: 276; Collier a Hoeffler 2005: 2; Bouzid 2011: 62), která jako jediná z výše popisovaných teorií reflektuje význam historicko-politického vývoje podílejícího se na utváření podmínek př́hodných pro realizaci převratu. Dle tohoto př́stupu $\mathrm{k}$ výzkumu StP představuje převrat značně negativní faktor, který se podepisuje na stabilitě politického systému: Ta degraduje s růstem počtu změn výkonné moci, jež mají nenormální (non-normal) povahu (Hanneman a Steinback 1990: 8) a byly uskutečněny mimoústavními 
(extraconstitutional) metodami (Belkin, Schofer 2003: 608). ${ }^{17}$ Množství badatelů aplikuje tuto teorii na výzkum VoP cíleně, avšak celá řada dalších přistupuje $\mathrm{k}$ analýze přícin převratu zpo̊sobem, který bud' $\mathrm{z}$ této teorie (někdy i zcela neúmyslně) vychází, anebo s ní alespoň sdílí klíčové předpoklady.

Nebezpečí „,sklapnutí pasti“ vzrůstá úměrně zvyšující se erozi politické kultury. Podstata této „černé díry stále se opakujících režimních změn generovaných armádou" (Collier a Hoeffler 2005: 3) tkví v narušení složitého mechanismu politického systému. Časté střídání vlád, násilné či pod hrozbou násilí vynucené změny ve vedení výkonné moci nebo poměrně krátké trvání po sobě jdoucích režimů (jejich institucionálních forem) vytváří a dále prohlubuje krizi systému (Hanneman a Steinback 1990: 8), jejímž hlavním důsledkem je postupná ztráta schopnosti samoregulace a obnovení jeho řádných interních pochodů. Po úspěšném, zpravidla vojenském převratu totiž dochází k řízenému oslabování pravomocí těch institucí, které se podílejí na soustavě brzd a protivah vůči nestandardnímu opanování moci a mezi něž patři zejména zákonodárný sbor a nezávislá justice (Belkin a Schofer 2003: 608).

Tato eroze „proti-převratového obranného systému“ není v rozporu se skutečností, že VoP bývá nezřídka následovaný „kontra-převratem“ (Zimmermann 1979: 277; Londregan a Poole 1990: 152). Ten je bud’to odpovědí opozice, v jejímž zájmu je zachování odstraňovaného režimu (zastavení probíhajícího převratu, popř. svržení nově se konsolidujícího režimu), anebo představuje reakci na zhoršení politického, ekonomického, sociálního či bezpečnostního prostředí způsobeného dřivějším př́evratem, jež se stal příslovečným „lékem horším než nemoc samotná“.

Praxe opakovaně prováděných VoP navíc posiluje korporátní identitu př́slušníků ozbrojených sil (viz schéma 9), s níž pracují také teorie vojenské dostřrednosti a teorie protiváhy (viz výše). Vytváři „spasitelský mýtus“ o armádě coby ochranitelce vlasti před vnitropolitickým chaosem nebo hrozbou zvenčí. $\mathrm{K}$ diskreditaci této ideje pak dochází vlivem neúspěšnosti VoP, prováděním protipřevratů a ztrátou legitimity převratem dosazeného režimu.

\footnotetext{
${ }^{17}$ Belkin a Schofer použili zajímavý výběr slov. Namísto výrazu „neústavní“ (nonconstitutional), které evokuje představu něčeho nepríjatelného, odsouzeníhodného a snad i nemyslitelného, termínem „mimoústavni““ zachycují podstatu problému pasti převratu. StP přináší bezprecedentní způsob změny vrcholné exekutivy, porušující ústavou zavedená pravidla vládní obměny. Tím však $\mathrm{v}$ důsledku vytváří precedens, jenž sice nemusí být součástí litery ústavy, ale zakládá přinejmenším neformální dojem legitimity. Převrat tak nadále nemusí být vnímán jako popírající ústavu, nýbrž jako možnost stojící nad ústavním pořádkem.
} 


\section{Schéma 9: Zjednodušený algoritmický model „pasti převratu“}

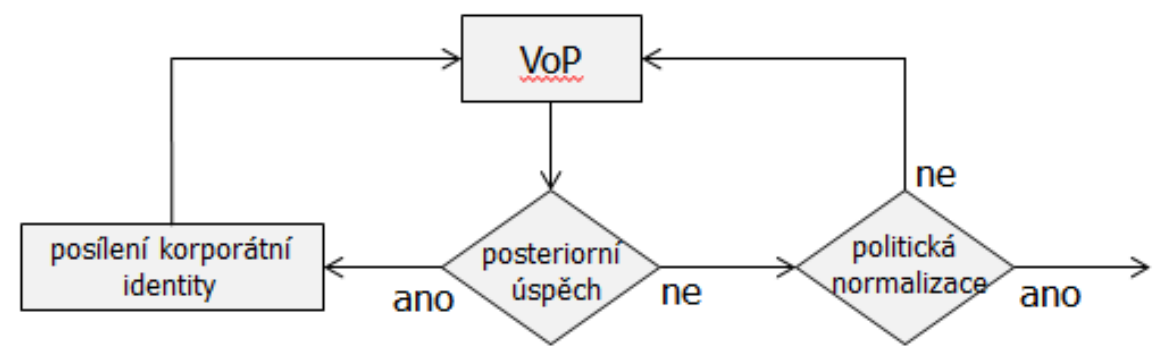

Zdroj: autor.

Riziko převratu, akcelerované převraty uskutečněnými $\mathrm{v}$ minulosti, se pochopitelně časem snižuje. V názoru na délku doby, během níž StP zvyšuje motivaci potenciálních konspirátorů k provedení dalšího převratu a během které tak představuje předchozí převrat spouštěcí faktor (StP nelze považovat za strukturální součást politického systému, poněvadž vždy překračuje hranice jeho komunikačního a interakčního soukolí, většinou definovaného ústavou) se badatelé rozcházejí. Rozpětí začíná třemi roky (Bouzid 2011: 62), pokračuje přes pět (Thompson a Christopherson 1979: 285), šest (Londregan a Poole 1990: 152) a končí deseti lety (Belkin a Schofer 2003: 608). Tato variabilita ve stanovování účinné doby pasivního ovlivňování společenských norem precedentem StP je v podstatě důsledkem odlišné metody výzkumu a odlišným výběrem zkoumané populace př́padů jednotlivými badateli. Nicméně při zhodnocení způsobu, jakým StP působí na vznik budoucích převratů, se zdá správnou možností období dokonce přesahující deset let. Jestliže totiž převrat vytváŕí precedens „ř́ešeni“ krizových situací a inkorporuje se do neformální normativního řádu společnosti, pak je vzpomínka na něj ,živá“ v paměti jeho současníků a ztrácí svou sílu teprve generační obměnou. Nelze tudíž vyloučit, že ovlivňuje rozhodování politických elit i mas po dobu trvající i 25 let (20-30 let vzhledem ke stále posouvajícímu se věku prvorodiček).

Historie bohatá na vojenské převraty a pokusy o ně vytváŕí specifický formální i neformální normativní řád, slovy J. Clarka (2007: 153) „kulturu vojenského intervencionismu“. Tato „patologická“ kultura oslabuje jistoty politického režimu, o které opírá svou existenci, a zvyšuje jeho zranitelnost vůči vnitřním (ale částečně i vnějším) bezpečnostním hrozbám, tedy i StP. Pro operacionalizaci proměnné „precedens převratu“ bývá tato definována jako realizovaný převrat nebo pokus o něj v období předcházejících dvaceti let. Někteři autoři do této doby zahrnují také jiné projevy politického násilí, jimiž jsou kupříkladu povstání nebo občanská válka (Londregan a Poole 1990: 154-155). 


\section{Závěr}

Deset teoretických př́stupů představuje deset možných pohledů na fenomén VoP z perspektivy př́čcin, které stojí u jeho vzniku. Taková přitažlivá variabilita, skýtající deset alternativních cest $\mathrm{k}$ výzkumu převratu a řadu př́ležitostí ke komparativním studiím hodnotícím rozsah aplikovatelnosti jednotlivých přístupů, však prúnáší podstatnou komplikaci: Jsou omezeny empirií, v níž jsou zakotveny. Jinými slovy, jedná se o deset možných vysvětlení vztahující se na deset množin prípadů, z nichž sice některé mohou sdílet společné parametry, povětšinou jsou ale př́liš specifické povahy na to, aby jednotlivě umožnily zakotvení teorie aplikovatelné všeobecně na celou populaci prípadů VoP. Badatel tak musí věnovat zvýšenou pozornost výběru vhodné substantivní teorie pro svůj výzkumný záměr a současně disponovat dostatečným apriorním poznáním, aby takového výběru byl schopen. I samotné substantivní teorie byly vyjádřeny postupným výzkumem převratů $\mathrm{v}$ geograficky charakteristickém prostř́edí bez přesahu do odlišných podmínek: Teorie vojenské dostřednosti tak byla kupř́kladu formulována na základě heuristického studia dějin latinskoamerických států; teorie protiváhy byla oproti tomu podložena empirií států Blízkého východu; autoři prací vytvářejících základ teorií pasti převratu nebo nákazy zase zaměřili svưj badatelský zájem na subsaharskou Afriku.

Výzkum státních převratů (nemluvě o výzkumu VoP) nemá potenciál, a snad ani ambice, stát se samostatnou subdisciplínou politických věd, protože epistemologicky, metodologicky a ani svým výzkumným subjektem nepřesahuje rámec studia politických systémů a tranzitologie. Neucelená teoretická výbava je zřejmě výsledkem spíše interpretativního zaměření výzkumu, upřednostňujícího studium konkrétních, časově i prostorově jasně vymezených historických událostí. Snahy badatelů v oblasti StP o formulaci všeobecně aplikovatelných postulátů naráží na empirickou limitovanost jejich individuálního zájmu, svazující výzkum v jeho samotných počátcích. Současný stav, v němž se výzkum StP nachází, lze popsat jako kvantitativně i kvalitativně rozsáhlou teoretizaci na substantivní úrovni. Stále nedošlo k sestavení formální, vševysvětlující „velkéc teorie StP (VoP). Logickým krokem k jejímu dosažení by byla syntéza substantivních prrístupů, která by nabývala formy syntetizovaného kauzálního modelu a soustavy několika hypotéz, jež by procesem validace (resp. falzifikace) zakotvily elementární axiomy (v ideálním prrípadě) či premisy teorie vojenského převratu. Tento krok bude obsahem budoucího př́spěvku autora článku.

Předložená analýza substantivních teorií VoP snad umožní rozvinout výzkum převratů $\mathrm{v}$ rámci české politologie. Jejich závěry však možná představují jednotlivé díly bezpochyby prrínosné formální teorie vojenského př̀evratu, ${ }^{18}$ který sice tvoři jen jednu ze subkategorií státního převratu, nicméně výskytem nejčastější a tím pádem

18 Nutno podotknout, že formální je teorie pouze z pohledu studia vojenských převratů. Z perspektivy výzkumu tranzitologických jevů, či jen státních převratů, nabývá tato teorie pochopitelně substantivní podoby. 
i nejvýznamnější. K její formulaci je však zapotřebí realizovat $v$ navazujícím výzkumu několik kroků. Zaprvé identifikovat základní koncepční rozdělení kauzálních faktorů VoP dle jejich vlivu a doby působení na politický systém. Zadruhé porovnat substantivní teorie a vytvořit konečný seznam faktorů, které jsou $\mathrm{v}$ dosavadním výzkumu VoP více či méně součástí vysvětlení jeho vzniku. Zatřetí $z$ tohoto seznam faktorů a $s$ rozpoznáním jejich odlišného charakteru sestavit komplexní kauzální model VoP shrnující dílčí závěry všech hlavních substantivních teorií. Začtvrté na základě takového modelu a poznání prríčinných vazeb mezi faktory a VoP jakožto závislou proměnnou (popř. mezi faktory navzájem) zformulovat zjednodušenou podobu formální teorie. A zapáté platnost teorii VoP ověřit empirickým výzkumem případových studií.

\section{Literatura a prameny}

Acemoglu, Daren, Simon Johnson, James Robinson a Pierre Yared (2008): „Income and Democracy.“ American Economic Review 91: 808-842.

Ades, Alberto a Hak Chua (1997): „Thy Neighbor's Curse: Regional Instability and Economic Growth." Journal of Economic Growth 2(3): 279-304. DOI: 10.1023/A:1009782809329

Agyeman-Duah, Baffour (1990): „Military Coups, Regime Change, and Interstate Conflicts in West Africa." Armed Forces \& Society 16(4): 547-570. DOI: 10.1177/0095327X9001600404

Arceneaux, Craig a David Pion-Berlin (2007): „Issues, Threats, and Istitutions: Explaining OAS Responses to Democratic Dilemmas in Latin America." Latin American Politics Society 49(2): 1-31. DOI: 10.1353/lap.2007.0016

Barany, Zoltan (2011): „The Role of the Military.“ Journal of Democracy 22(4): 24-35. DOI: 10.1353/jod.2011.0069

Barany, Zoltan (2013): „Armies and Revolutions.“ Journal of Democracy 24(2): 62-76. DOI: 10.1353/jod.2013.0024

Barraca, Steven (2007): „Military Coups in the Post-cold War Era: Pakistan, Ecuador and Venezuela." Third World Quarterly 28(1): 137-154. DOI: 10.1080/01436590601081948

Belkin, Aaron a Evan Schofer (2003): „Toward a Structural Understanding of Coiup Risk.“ Journal of Conflict Resolution 47(5): 594-620. DOI: 10.1177/0022002703258197

Belkin, Aaron a Evan Schofer (2005): „Coup Risk, Counterbalancing, and International Conflict." Security Studies 14(1): 140-177. DOI: 10.1080/09636410591002527

Ben-Eliezer, Uri (1998): „Is a military coup possible in Israel? Israel and French-Algeria in comparative historici-sociological perspective." Theory and Society 27(3): 311-349. DOI: 10.1023/A:1006849601528

Bouzid, Bechir (2011): „Using a Semi-Parametric Analysis to Understand the Occurrence of Coups d'État in Developing Countries." International Journal of Peace Studies 16(2): 53-79. Brass, Paul (1985): „Ethnic Groups and the State.“ In Paul Brass (ed.), Ethnic Groups and the State. Totowa, N.J.: Barnes \& Noble, 1-57.

Brauner, Jennifer (2012): „Military Spending and Democratization.“ Peace Economics, Peace Science and Public Policy 18(3): 1-17. 
Casper, Gretchen (1991): „Theories of Military Intervention in the Third World: Lessons from the Philippines." Armed Forces \& Society 17(2): 191-210. DOI: 10.1177/0095327X9101700202

Cederman, Lars-Erik, Andreas Wimmer a Brian Min (2010): „Why Do Ethnic Groups Rebel? New Data Analysis“ World Politics 62(1): 87-119. DOI: 10.1017/S0043887109990219

Clark, John (2007): ,The Decline of the African Military Coup.“ Journal of Democracy 18(3): 141-155. DOI: $10.1353 /$ jod.2007.0044

Cleary, Matthew (2006): ,'Left Turn' in Latin America? Explaining the Left's Resurgence.“ Journal of Democracy 17(4): 35-49. DOI: 10.1353/jod.2006.0058

Collier, Paul a Anke Hoeffler (2005): Coup Traps: Why does Africa have so many Coups d'État? Working Paper, Centre for the Study of African Economies, University of Oxford.

Collier, Paul a Anke Hoeffler (2007): Military Spending and the Risks of Coups d'État. Working Paper, Centre for the Study of African Economies, University of Oxford.

Dix, Robert (1994): „Military coups and military rule in Latin America.“ Armed Forces \& Society 20(3): 439-456. DOI: 10.1177/0095327X9402000307

Feaver, Peter (1999): „Civil-Military Relations.“ Annual Review of Political Science 2: 211-241.

DOI: 10.1146/annurev.polisci.2.1.211

Finer, Samuel (1962): The Man on Horseback: The Role of the Military in Politics. Boulder: Westview.

Friedrich, Carl (1969): „The Evolving Theory and Practice of Totalitarian Regimes.“ In Carl Friedrich, Michael Curtis a Benjamin Barber (eds.), Totalitarianism in Perspective: Three Views. New York: Praeger, 123-164.

Gans-Morse, Jordan (2004): „Searching for Transitologists: Contemporary Theories of Post-Communist Transitions and the Myth of a Dominant Paradigm." Post-Soviet Affairs 20(4): 320-349.

Geddes, Barbara (1999): „What do we Know About Democratization After Twenty Years?" Annual Review of Political Science 2: 115-146. DOI: 10.1146/annurev.polisci.2.1.115 Goldstone, Jack et al. (2010): „A Global Model for Forecasting Political Stability.“ American Journal of Political Science 54(1): 190-208. DOI: 10.1111/j.1540-5907.2009.00426.x

Haneman, Robert (1986): „Military Elites and Political Executives.“ Journal of Political and Military Sociology 14(4): 75-89.

Hanneman, Robert a Robin Steinback (1990): „Military Involvement and Political Stability: An Event History Analysis 1940-1980.“ Journal of Political and Military Sociology 18(1): 1-23. Horowitz, Donald (1985): Ethnic Groups in Conflict. Berkeley and Los Angeles: University of California Press.

Huntington, Samuel (1957): The Soldier and the State. Harvard: Harvard University Press.

Huntington, Samuel (1968): Political Order in Changing Societies. New Haven and London: Yale University Press.

Huntington, Samuel (1991): The Third Wave. Norman, OK: University of Oklahoma Press. Iqbal, Zaryab a Harvey Starr (2007): State Failure: Conceptualization and Determinants. Working Paper, University of South Carolina.

Iqbal, Zaryab a Harvey Starr (2008): „Bad Neighbors: Failed States and Their Consequences." Conflict Management and Peace Science 25(4): 315-331. DOI:

10.1080/07388940802397400 
Jackman, Robert (1978): „The Predictability of Coups d'État.“ American Political Science Review 72(4): 1262-1275.

Janowitz, Morris (1977): Military Institutions and Coercion in the Developing Countries. Chicago: University of Chicago Press.

Jenkins, Craig a Augustine Kposowa (1990): „Explaining Military Coups d’État: Black Africa, 1957-1984.“ American Sociological Review 55(6): 861-875.

Jenkins, Craig a Augustine Kposowa (1992): „The Political Origins of African Military Coups.“ International Studies Quarterly 36(3): 271-292.

Jia, Ruixue a Pinghan Liang (2012a): Government Structure and Military Coups. Working Paper, Institute for International Economic Studies, Stockholm University, Stockholm.

Jia, Ruixue a Pingham Liang (2012b): „Decentralization and Military Coups.“ In Chen Bo, Manas Chatterij a Hao Chaoyan (eds.), Cooperation for a Peaceful and Sustainabla World, Part 1. Bingley: Emerald Group Publishing.

Johnson, Thomas, Robert Slater a Patrick McGowan (1984): „Explaining African Military Coups d'Etat, 1960-1982.“ American Political Science Review 78(3): 622-640.

Johnstad, Petter (2012): „When the Time Is Right: Regime Legitimacy as a Predictor of Nonviolent Protest Outcome.“ Peace \& Change 37(4): 516-543. DOI: 10.1111/j.14680130.2012.00769.x

Keohane, Robert a Joseph Nye (1987): „Power and Interdependence.“ International Organization 41(4): 725-753.

Korpi, Walter (1974): „Conflict, Power and Relative Deprivation.“ American Political Science Review 68(4): 1569-1578.

Kposowa, Augustine a Craig Jenkins (1993): „The Structural Sources of Military Coups in Postcolonial Africa, 1957-1984.“ American Journal of Sociology 99(1): 126-163.

Leon, Gabriel (2012): Loyalty for Sale? Military Spending and Coups d'État. Working Paper, University of Cambridge.

Levitsky, Steven a Lucan Way (2005): „International Linkage and Democratization.“ Journal of Democracy 16(3): 20-34. DOI: 10.1353/jod.2005.0048

Levitsky, Steven a Lucan Way (2006): „Linkage Versus Leverage: Rethinking the International Dimension of Regime Change." Comparative Politics 38(4): 379-400. DOI: $10.2307 / 20434008$

Linz, Juan (2000): Totalitarian and Authoritarian Regimes. London: Lynne Rienner Publishers.

Lissak, Moshe (1973): „Stages of Modernization and Patterns of Military Coups.“ International Journal of Comparative Sociology 14(1-2): 59-75.

Londregan, John a Keith Poole (1990): „Poverty, the Coup Trap, and the Seizure of Executive Power.“ World Politics 17(2): 151-183.

Lunde, Tormod (1991): „Modernization and Political Instability: Coup d'état in Africa, 1955-1985.“ Acta Sociologica 34(1): 13-32.

Martinák, Lukáš (2010): „Armáda jako protidemokratický aktér: př́ipadová studie Sýrie a Pákistánu“. Politologická revue 16(2): 51-76.

Martinák, Lukáš (2011): Politika mocenské rovnováby: definice v parametrech státu a koncert velmocí 1815-1854. Diplomová práce na katedře politologie a evropských studií Filozofické fakulty Univerzity Palackého v Olomouci. Olomouc: Univerzita Palackého v Olomouci.

Martinák, Lukáš (2015): „Názvosloví studií státního převratu: jeho použití v odborné literatuře, 1962-2014.“ Stredoevropské politické studie 17(1): 88-119. DOI: 10.5817/CEPSR.2015.1.88 
Mbaku, John (1994): „Military Coups as Rent-Seeking Behavior.“ Journal of Political and Military Sociology 22(3): 241-284.

McGowan, Patrick (1975): „Predicting Instability in Tropical Africa.“ In Michael O’Leary a William Coplin (eds.), Quantitative Analysis in Foreign Policy and Forecasting. New York: Praeger, 35-78.

McGowan, Patrick (2005): „Coups and Conflict in West Africa, 1955-2004.“ Armed Forces \& Society 32(1): 5-23. DOI: 10.1177/0095327X05277885

Morrison, Donald a Hugh Stevenson (1972a): „Integration and Instability.“ American Political Science Review 66(3): 902-927.

Morrison, Donald a Hugh Stevenson (1972b): „Cultural Pluralism, Modernization and Conflict." Canadian Journal of Political Science 5(1): 82-103.

Nordlinger, Eric (1977): Soldiers in Politics. Englewood Cliffs, N.J.: Prentice-Hall.

O'Kane, Rosemary (1993): „Coups d'État in Africa: A Political Economy Approach.“ Journal of Peace Research 30(3): 251-270.

Perlmutter, Amos (1969): „The Pretorian State and the Pretorian Army.“ Comparative Politics 3(3): 382-404.

Powell, Jonathan (2012): „Determinants of the Attempting and Outcome of Coups d'État.“ Journal of Conflict Resolution 56(6): 1017-1040. DOI: 10.1177/0022002712445732

Powell, Jonathan (2014): „An assessment of the 'democrartic' coup theory.“ African Security Review 23(3): 213-224.

Putnam, Robert (1967): „Toward Explaining Military Intervention in Latin America Politics.“ World Politics 20(1): 83-110.

Quinlivan, James (1999): „Coup-proofing: ITs Practice and Consequences in the Middle East.“ International Security 24(2): 131-165.

Rabushka, Alvin a Kenneth Shepsle (1972): Politics in Plural Societies. Columbus: Charles Merrill.

Remmer, Karen (1992): „The Process of Democratization in Latin America.“ Studies in Comparative International Development 27(4): 3-24.

Rittinger, Eric a Matthew Cleary (2013): „Confronting Coup Risk in the Latin American Left." Studies in Comparative International Development 48(4): 403-431. DOI: 10.1007/s12116-013-9128-9

Roessler, Philip (2011): „The Enemy Within. Personal Rule, Coups, and Civil War in Africa." World Politics 63(2): 300-346. DOI: 10.1017/S0043887111000049

Smaldone, Joseph (1974): „The Paradox of Military Politics in Sub-Saharan Africa.“ In Charles Cochran (ed.), Civil-Military Relations. New York: Free Press, 203-227.

Šaradín, Pavel. (2008): Teorie voleb drubého rádu a možnosti jejich aplikace v České republice.

Olomouc: Univerzita Palackého v Olomouci

Thompson, William (1974): „Toward Explaining Arab Military Coups.“ Journal of Political and Military Sociology 2(2): 237-250.

Thompson, William (1975): „Regime Vulnerability and the Military Coup.“ Comparative Politics 7(4): 459-487.

Thompson, William a Jon Christopherson (1979): „A Multivariate Analysis of the Correlates of Regime Vulnerability and Proneness to the Military Coup." Journal of Political and Military Sociology 7(2): 283-289.

Wayman, Frank a Atsushi Tago (2009): „Explaining the Onset of Mass Killing, 1949-87.“ Journal of Peace Research 20(10): 1-17. DOI: 10.1177/0022343309342944 
Weber, Max (1978): Economy and Society. An Outline of Interpretive Sociology. Berkeley: University of California Press.

Wells, Alan (1974): „The Coup d'état in Theory and Practice: Independent Black Africa in the 1960s." The American Journal of Sociology 79(4): 871-887.

Wells, Alan a Richard Pollnac (1988): „The Coup d'état in Sub-Saharan Africa: Changing Patterns from 1956-1984." Journal of Political and Military Sociology 16(4): 43-56.

Zimmermann, Ekkart (1979): Political Violence, Crises, and Revolutions: Theories and research. Cambridge: Alfred Schenkman Publications.

\section{Substantive Theories of Military Coup: Causal Factors SUMMARY}

The military coup has been the main focus of interest of a number of political science scholars, notably of Anglo-Saxon origin, since the 1960s. One of the main issues (perhaps the most important) that the current study sought to address is the chain of causation associated with military coups: When do military coups occur (i.e. what are the necessary conditions for their occurrence)?; What are the causes of such coups (i.e. what are the critical factors governing their implementation - ideally speaking, what are the sufficient conditions for such coups to occur)?. Given the importance of these questions, dozens of theories and corresponding causal models explaining the emergence of military coups have been developed, each of them stressing the presence of different causal factors. To some extent, they complement each other, but in some cases they are in conflict, one excluding the other. This fragmentation of military coup (or the coup d'état in more general terms) research is perceptible in the light of efforts to express a universal, formal military coup theory, yet each one of the substantive theories offers an alternative explanation for the emergence and success of the coup in specific cases, definable by a set of specific causal factors.

Military centrality theory, one of the mainstream approaches, represents a heuristic study of the role of the military, mostly in developing societies. The student of military coup research who decides to use it is confronted with several limitations. First, this theory ignores the part played by the government in events antecedent to a military coup (or plot). The theory reduces it to a decision-making process regarding the financing of the army. Second, the theory does not include characteristics of the political environment in military coup risk assessment. The type of political regime is considered irrelevant in spite of the disproportion in the numbers of coups between democratic and authoritarian regimes. Third, military centrality theory does not sufficiently reflect intra-military dynamics. Its simple holistic reception of the institution of the armed forces ignores the complexity of the military's internal structure (the phenomenon of factionalism represents the lone exception). The theory fails in its effort to explain the effect of conflict lines inside the military structure on the civil-military interaction.

The conceptual approach, which can be called the "theory of counterbalancing", corrects some deficiencies of military centrality theory. A too holistic understanding of the 
military is slightly moderated by the concept of a "parallel army", which plays the role of a structural "coup proofing" element. Despite this partial correction, a conceptual gap in the form of the absence of political regime characteristics in coup risk assessment still persists. The significance of this in the consideration of military coup causality is highlighted by the counterbalancing theory itself, as the different consequences of a low level of defense spending in democratic and authoritarian regimes are obvious.

The remaining substantive theories also labor with conceptual limitations. The theory of ethnic antagonism, the theory of contagion, the leverage and linkage hypothesis, the coup trap theory - each of them has the potential to explain military coup causality in a specifically defined set of cases. This engenders the belief that a formal generally applicable theory of military coup is needed. However, formulating such a theory is a challenge for future additive research.

The article lays the foundations for facing up to this challenge: It presents a descriptive overview of the prevailing theoretical approaches in military coup research (as a subset of the category of the coup d'etat); analyzes them through different prisms; and evaluates them critically. The article includes ten sections, each dealing with a particular theoretical/conceptual approach to military coups, none of which have been adequately reflected in national research on the topic. This, after all, applies to the research of coup d'état as a whole. The paper attempts to offer Czech political scientists new research tools in the sphere of military coup studies and to reduce the substantial gap between Czech and Anglo-Saxon political science in this area. 